\title{
EPIDOTE-BEARING CALC-ALKALIC GRANITOIDS IN NORTHEAST BRAZIL
}

\author{
ALCIDES NÓBREGA SIAL*
}

\begin{abstract}
RESUMO GRANITÓIDES COM EPÍDOTO MAGMÁTICO NO NORDESTE DO BRASIL. Um grande número de granitóides cálcio-alcalinos com epidoto são encontrados no Domínio Estrutural Central (DEC) - que compreende três segmentos: Seridó, Cachoeirinha-Salgueiro e Riacho do Pontal - e em algumas outras localidades no Nordeste do Brasil. No cinturão Cachoerinha-Salgueiro (CCS), granodioritos e tonalitos com epidoto, meta a peraluminosos, intrudiram fllitos há cerca de $620 \mathrm{Ma}$, enquanto no Seridó, uma maior variedade de plutões com epfdoto fgneo intrudiu gnaisses Jucurutu ou xistos Seridó. Granodioritos com duas micas com $( \pm)$ granada e epfdoto ígneo (?) intrudiram metassedimentos do Cinturão Riacho do Pontal. Epídoto magmático está também presente nos plutões trondhjemítícos e shoshonítícos - que intrudiram, respectivamente, xistos Salgueiro e rochas de embasamento ao longo do limite sul do CCS - bem como em plutões no Complexo Surubim-Caroalina e nos cinturões Pajed-Paraíba e Sergipano. E encontrado em quatro relações texturais, duas das quais indiscutivelmente magmáticas, e duas outras de reações subsolidus. No CCS, granitóides com epfdoto solidificaram-se geralmente em torno de $6 \mathrm{kbar}-7 \mathrm{kbar}$, de acordo com seus teores de Al na homblenda. Pressões mais baixas obtidas para encraves quartzo - dioríticos são devidas à perda de $\mathrm{Al}$ através de reação subsolidus com plagioclásio, produzindo epídoto granular. Diferem de granitóides mesozóicos similares na América do Norte porque, embora suas pressões de solidificação sejam altas, eles intrudiram tanto metassedimentos da fácies xistos verdes como plutões paleozóicos na Argentina (Cadeias Pampeanas), Nova Inglaterra (área de Sherbrooke-Lewiston) e Nova Zelândia (Cadeia de Vitória). No CCS, estes granitóides exibem moderados $\mathrm{Sr}$, Ba e $\mathrm{Zr}$ e baixo $\mathrm{Nb}(<20$ ppm); são enriquecidos em terras raras leves e empobrecidos em terras raras pesadas, com anomalia negativa de Eu variável. No Seridó (p. ex., o batólito de São Rafael), os granitóides são mais altos em $\mathrm{Sr}$, com teores de Ba equivalentes àqueles dos granitóides do $\mathrm{CCS}$, com $\mathrm{Zr}$ levemente mais alto e baixo $\mathrm{Nb}$. Exibem padrões de terras raras menos inclinados e ausência de anomalia de $\mathrm{Eu}$. No Riacho do Pontal, os granitóides exibem teores de $\mathrm{Sr}, \mathrm{Ba}$ e $\mathrm{Nb}$ equivalentes aos observados no CCS, Zr duas vezes mais alto, e padrões de terras raras com inclinação negativa, sem ou com apenas discreta anomalia de Eu plutões com epfdoto no CCS exibem alto $\delta^{18} \mathrm{O}(11$ permil - 13 permil), e xenólitos de anfibolito exibem $\delta^{18} \mathrm{O}$ em torno de 10,5 permil. Plutões equivalentes no Seridó exibem valores de $\delta^{18} \mathrm{O}(6$ permil -8 permil) levemente mais baixos do que os típicos para tonalitos e trondhjemitos no noroeste da América do Norte (7,5 permil - 9,0 permil; p. ex., Complexo de Hazard Cre$\mathrm{ek}$, Idaho). Isto demonstra que plutões com epídoto podem formar-se a partir de mais de um tipo de material fonte, geralmente com a presença de um componente no magma derivado de sedimentos ou rochas vulcânicas. Processos levando à sua formação são repetidos através do tempo geológico em diferentes níveis crus-
\end{abstract} tais.

Palavras-chaves: Epídoto, cálcio-alcalino, isótopos de oxigênio, Pré-Cambriano.

\begin{abstract}
A large number of Late Precambrian calc-alkalic epidote-bearing granitoids are found in the Central Structural Domain (CSD) - which comprises three segments: Seridó Fold Belt (SFB), Cachoeirinha-Salgueiro Fold Belt (CSF), and Riacho do Pontal Fold Belt (RPF) - and in some other localities in Northeast Brazil. In the CSF, meta to peraluminous, epidote-bearing granodiorites and tonalites intruded phyllites around $620 \mathrm{Ma}$ ago, while in the SFB a larger variety of plutons with igneous epidote intruded Jucurutu gneisses and Seridò schists. Two-mica granodiorites with $( \pm)$ garnet and igneous epidote (?) intruded amphibolite-grade metasediments of the RPF. Magmaric epidote is also present in tcondhjemitíc and shoshonitic plutons that intruded, respectively, Salgueiro schists and basement rocks along the southern boundary of the CSF, as well as in plutons in the Surubim-Caroalina complex, Pajeú-Paraíba and Sergipean Fold Belts. It is found in four textural relationships, two of which indisputably magmatic and two others of sub-solidus reactions. In the CSF, epidote-bearing granitoids solidified, with one exception, around $6 \mathrm{kbar}-7 \mathrm{kbar}$, according to their Al contents in hornblende. Lower pressures obtained for quartz diorite enclaves are due to Al loss through sub-solidus reaction with plagioclase producing granular epidote. They differ from similar Mesozoic granitoids in North America because, although their pressures of solidification are high, they intruded greenschist fades metasediments likewise Paleozoic plutons in Argentina (Pampean Ranges), New England (Sherbrooke-Lewiston area) and Nov Zealand (Victoria Ranges). In the CSF, these granitoids exhibit moderate $\mathrm{Sr}, \mathrm{Ba}$ and $\mathrm{Zr}$, low $\mathrm{Nb}(<20 \mathrm{ppm})$ are LREE-enriched and HREE-depleted, with variable negative Eu anomaly. In the SFB (e.g. São Rafael batholith,), granitoids are higher in Sr, with $\mathrm{Ba}$ contents equivalent to the CSF granitoids, Zr slightly higher and low $\mathrm{Nb}$. They exhibit less sterep REE-patterns and lack Eu anomaly. In the RPF, granitoids display Sr, $\mathrm{Ba}$ and $\mathrm{Nb}$ contents equivalent to those in the CSF, $\mathrm{Zr}$ twice as high, and REE patterns with negative slope lacking or exhibiting a discrete Eu anomaly. Epidote - bearing plutons in the CSF exhibit high $\delta^{18} \mathrm{O}(11$ permil - 13 permil), and amphibplite xenoliths, probably from the source, have $\delta^{18} \mathrm{O}$ around 10.5 permil. Equivalent plutons in the SFB display $\left.\delta^{18} \mathrm{O}\right)$ values $(6$ permil - 8 permil) slightly lower than those typical for epidote-bearing tonalites and trondhjemites in northwestern North America (7.5 permil - 9.0 permil, e.g., Hazard Creek Complex, Idaho). This demonstrates that epidote-bearing plutons originate from more than one kind of source material, always in the presence of a component in the magma derived from sedimentary or altered volcanic rocks. Processes leading to their formation are repeated through geological time and magmas intrude different crustal levels.
\end{abstract}

Keywords: Epidote, calc-alkalic, oxygen isotopes, Precambrian.

INTRODUCTION Although epidote is known as a common metamorphic mineral, only in the 80 's it has been identified in nature as a primary, igneous phase in granitoid rocks (Zen \& Hammarstrom 1984). Its presence was recorded in Mesozoic tonalites and granodiorites within the North American Cordillera, which occur in a well-defined, 
discontinuous belt of plutonic rocks $(=2000 \mathrm{~km})$, extending from Southeast Alaska, west of the Coast Range megalineament, to Northern California (Zen 1985). In addition, Moench (1986) recognized primary epidote in Devonian granodiorites to quartz- diorites in New England (Maine and NewHampshire). The most convicing evidence of magmatic epidote is given by Evans \& Vance (1987) and Dawes (1988) who described epidote phenocrysts in dacitic dikes in Colorado, United States.

Although the petrologic importance and implications of magmatic epidote-bearing plutons on crustal evolution have been enhanced through several publication (e.g. Zen \& Hammarstron 1984, Zen 1985, among others) very little has been reported on epidote-bearing granitoids outside North America. Their occurrence has been recognized in Late Precambrian calc-alkalic, peraluminous to metaluminous granitoids of Northeast Brazil (Sial 1986, Suva 1989, Sial \& Ferreira 1989, Souza \& Sial 1989) and in Ordovician granites of Northern Pampean Ranges, Argentina (Saayedra et al. 1987, Toselli et al. 1987), where a group of peraluminous, two-mica granitoids contain igneous epidote. Besides, Tulloch (1986) described epidote as a common accessory mineral in granites to granodiorites in the Victoria Range of New Zealand.

The presence of epidote in tonalites and granodiorites suggests that the pluton crystallized under lithostatic pressures of at least $6 \mathrm{kbar}$ (Zen \& Hammarstrom 1984). This assumption is based on (a) phase equilibria $\left(8 \mathrm{kbar}, 600^{\circ} \mathrm{C}\right.$ $800^{\circ} \mathrm{C}$ ) of synthetic granodioritic melts (Nancy 1983); (b) epidote stability curve which intersects the liquidus curve of tonalitic melts only at presure $\geq 6 \mathrm{kbar}$, (c) pressure of regional tectonism and synchronous metamorphism. The knowledge of the depth of solidification of these plutons has been used to estimate the minimum rate of regional uplift.

The primary scope of this study is to analyse the geographic distribuition of epidote-bearing granitoids in Northeast Brazil by (a) searching for possible compositional trends, (b) determining their relative depth of emplacement (c) collating the existing and newly acquired oxygen isotope data with oxygen data from epidote-bearing granitoids in North America, and (d) cataloguing the field and geochemical characteristics of these rocks to help constraining the main variables concerning their formation and the tectonic conditions under which they develop.

\section{EPIDOTE-BEARING PLUTONS IN NORTHEAST}

BRAZIL Epidote-bearing tonalites and granodiorites were found intruding metasediments of the Precambrian Cachoeirinha-Salgueiro Fold Belt (CSF, Fig. 1) in central Northeast Brazil (Sial 1984, 1986, 1987, Sial \& Ferreira 1989) which represents one of the three segments in the Central Structural Domain (CSD, Fig. 1). Recently Sial \& Ferreira (1989) and Souza \& Sial (1989) recorded the presence of igneous epidote in granitoids in the Seridó Fold Belt (SFB), the northernmost of the three segments which compose the CSD.

Magmatic epidote is also present in granitoids in the Riacho do Pontal Fold Belt (RPF), the southernmost of the three segments of the CSD. Outside this domain, it is found in plutons in the Pajeú-Paraíba Belt and Santa Cruz do Capibaribe region (part of the Surubim-Caroalina complex as defined by Brito Neves (1983) (Fig. 1). In addition, epidote has been identified as a common accessory phase in the Quixadá batholith (Silva 1989), state of Ceará and in granitoids to the north of Lurdes, state of Sergipe (J.M. Rangel, personnel communication, 1990).

Field Characteristics and Petrography Epidote in granitoids in Northeast Brazil was initially described by Sial \& Menor (1969) in epidote-tonalites dikes near Santa Cruz do

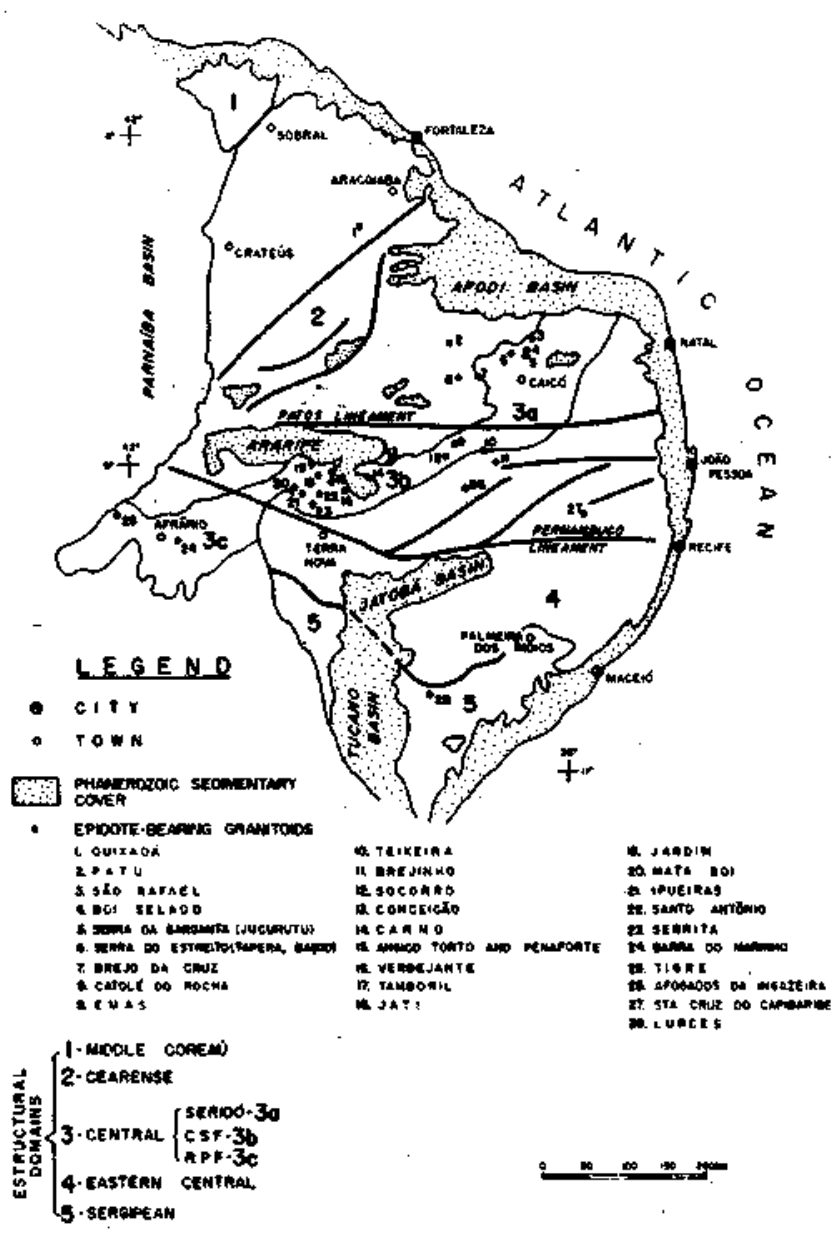

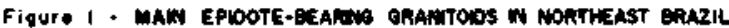

Figure 1-Map of Northeast Brazil showing the location of the main epidote-bearing plutons (modified from Sial 1987). Cachoeirinha-Salgueiro Fold Belt (CSF); Riacho do Pontal Fold Belt (RPF); Central Structural Domain (CSD) Figura 1 - Mapa do Nordeste do Brasil mostrando a localização dos principais plutões com epfdoto magmátíco (modificado de Sial 1987). Cinturão Cachoeirinha-Salgueiro (CSF); Cinturão Riacho do Pontal (RPF); Domínio Estrutural Central (CSD)

Capibaribe, state of Pernambuco and at the Pedra Branca granodiorite, south of Itaporanga, in the state of Paraíba (Almeida et al. 1971). Today over fifty Precambriam granitic plutons in central Northeast Brazil are known to contain igneous epidote (Sial, 1984, 1986). Many of these plutons are of the so-called Conceição-type (Almeida et al. 1971), a denomination that should be restricted, however, to tonalites and granodiorites which exhibit igneous epidote, and textura! patterns common in the type locality (e.g. oscillatorily zoned plagioclase with subhedral epidote inclusions in the cores, besides high $\delta^{18} \mathrm{O}$ as redifined by Sial $(1984,1986)$.

Outside the CSF, however, epidote-bearing granitoids have textural and geochemical characteristics which differ from the Conceição-type granitoids.

In all cases, epidote tends to be associated with the mafic minerals and where banding exists, it tends to be in the mafic layers. There are four different textural types of epidote, 
whose size in some cases reaches about $1 \mathrm{~mm}$ across.

Type 1 epidote appears as euhedral to .subhedral, sometimes elongate crystals (Photo 1) with length/width of $3 / 1$ to $10 / 1$ included in the core of plagioclase phenocrysts. Euhedral to subhedral type II epidote with euhedral, oscillatorily zoned allanite core (Photo 2) is relatively common, but euhedral to subhedral type III epidote, rimmed or included in biotite (Photo 3), lacking allanite core is by far the most common form of epidote occurrence. Finally, a fourth type is rare and represented by granular epidote (Photo 4) along the boundaries of hornblende or less often biotite, in contact with plagioclase. Almost always this type is observed in mafic enclaves which probably represent magma globules quenched against a granodiorite host. Types II and III seem to be definitely of magmatic origin while type IV, resulted from subsolidus reaction of hornblende with plagioclase and type I from breakdown of calcic cores of plagioclase. These are plagioclase cores brought up along the magma, from the source, and around which oscillatorily zoned plagioclase grew. As they were unstable, during cooling they broke down allowing zoisite crystals to grow. Another interpretation is that these calcic cores crystallized from the injection of more mafic magma that broke down and gaye rise to zoisite crystals and were surrounded by oscillatorily zoned plagioclase in a convectine maema chamber.

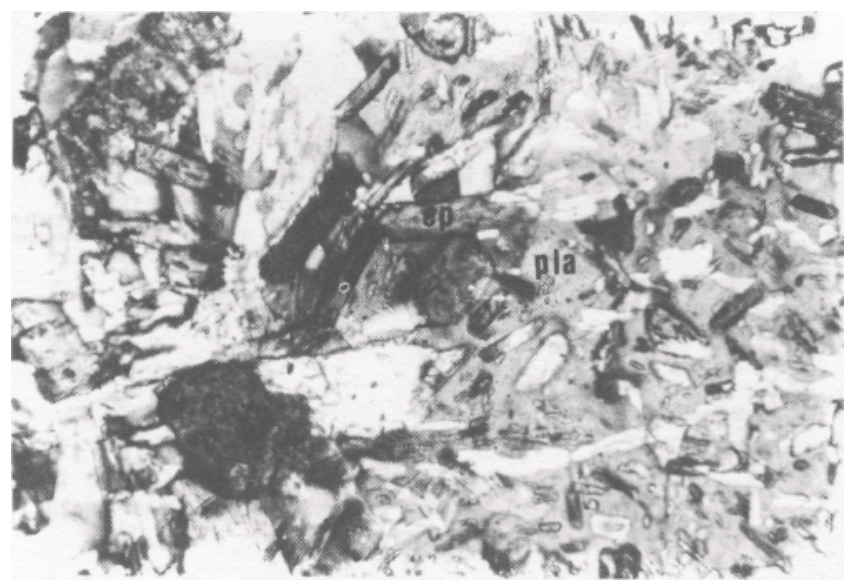

I'hoio I - I'rismatic crystals of epidote (type 1) in a granodiorite at Angico Tono, Pernambuco (Cachoeirinha-Salgueiro Fold Belt). Crossed polar s and 160X magnification. $E p=$ epidote; pla $=$ plagioclase Foto 1 - Cristais prismáticos de epidoto (tipo 1) num granodiorito em Angico Torto, Pernambuco (CSF). Nicois cruzados e aumento de 160 vezes. $\mathrm{Ep}=$ epfdoto; $\mathrm{pla}=$ plagioclásio

Amphibole-rich quartz-diorite enclaves are present in most epidote-bearing tonalites and granodiorites. They are unfoliated, black, uniformly fine-grained and often show features of liquid-liquid contact (acicular apatite in chilled margins, crenulated contacts, and elongate amphiboles indicating quenching). Invariably, they exhibit pyroxene partially or completely uralitized, sometimes with symplectitic texture, elongate amphibole, plagioclase, poikilitic K-feldspar (in typical texture of undercooling), granular epidote, acicular apatite, minor Fe-oxide minerals and have not obviously been affected by the host granite. Angular to subangular amphibolite enclaves are present in the quartz-diorite inclusions and in the host granodiorites or tonalites. In some cases these enclaves are fringed by biotite or amphiboles and perhaps represent fragments of the source rocks for the magmas once they are present in all of the studied Conceição-type plutons within the extension of the CSF.

Table 1 summarizes the major occurrences of

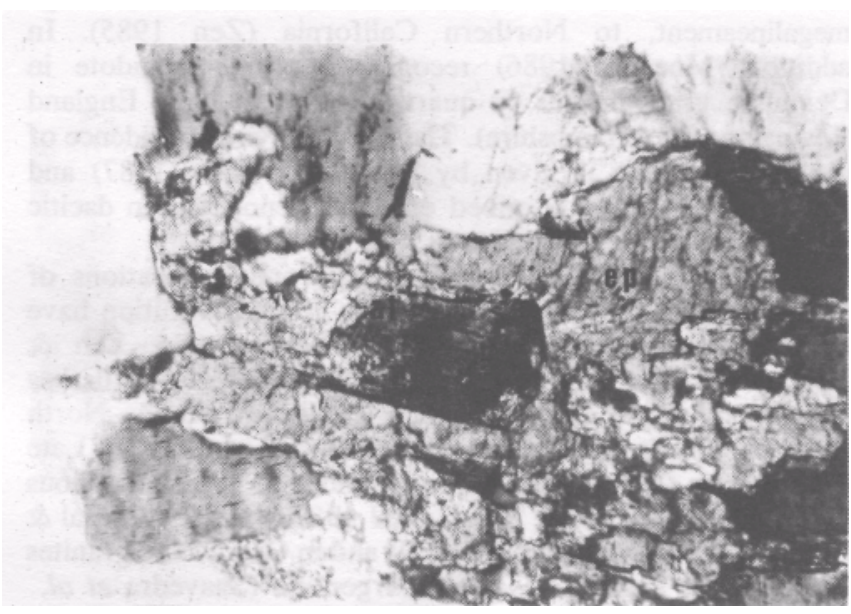

Photo 2 - Igneous epidote with zoned allanite core (type II) in contact with biotite in the São Rafael batholith, Seridó Fold Belt, Rio Grande do None. Crossed polars and $63 X$ magnification. $E p=$ Epidote; al - allanite Foto 2 - Epidoto ígneo com núcleo de allanita zonada (tipo ID em tato com biotita no batólito de São Rafael (SFB), Rio Grande do Norte. Nicois cruzados e aumento de 63 vezes. Ep = epidoto; al = allanita

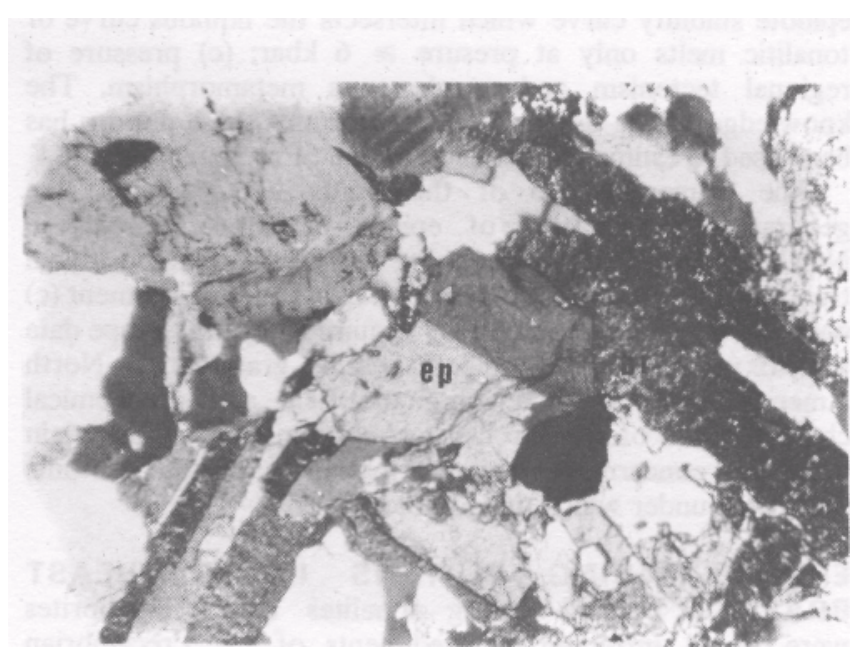

Photo 3 - Igneous, twinned epidote without allanite core (type III) in contact with biotite in the São Rafael pluton, Seridó Fold Belt, state of Rio Grande do None. Crossed polars and $63 \mathrm{X}$ magnification. Ep = epidote; $b i=$ biotite

Foto 3 - Epidoto ígneo, geminado, sem núcleo de allanita (tipo III) em contato com biotita no batólito de São Rafael (SFB), Rio Grande do Norte. Nicois cruzados e aumento de 63 vezes. Ep = epidoto; bi = biotita

epidote-bearing granitoids in the CSD and elsewhere in Northeast Brazil. There are several other plutons in the CSF not included in this table which are epidote-bearing but lack geological information (e.g. Tempe, Sítio Serrote Preto, Lagoa Nova, Açude das Abóboras, all near Serrita town, state of Pernambuco; Socorro and Santana dos Garrotes, near Piancó, states of Paraíba.)

a. The Cachoeirinha-Salgueiro Fold Belt (CSF) The largest concentration of plutons of this kind in Northeast Brazil intruded Cachoeirinha phyllites (Fig. 1) in the CSF around $620 \mathrm{Ma}$ (Sial \& Ferreira 1989). They usually form 


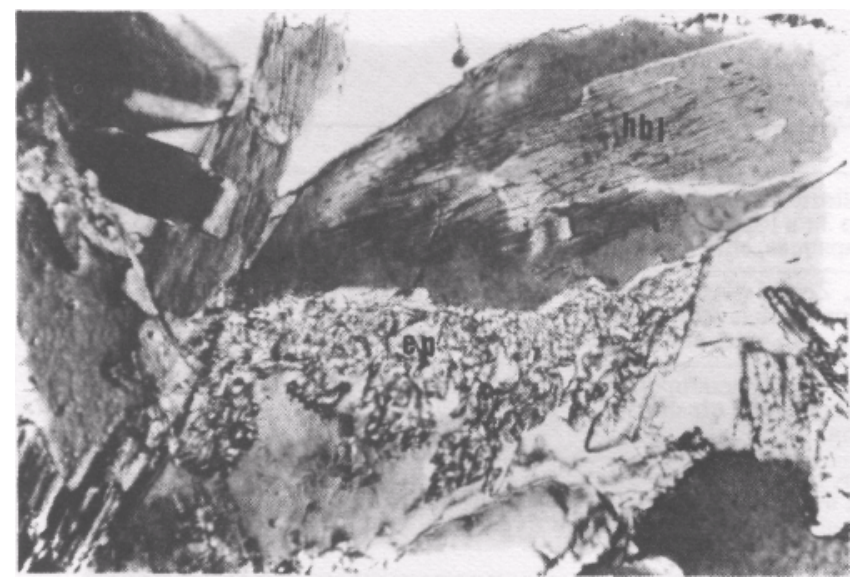

Photo 4 - Granular epidote (type IV) along the boundary of amphibole in contact with plagioclase in a quartz-diorite enclave in the calk-alkalic stock at Conceição, Paraiba (Cachoeirinha-Salgueiro Fold Belt). Crossed polars, 63X magnification. $E p=$ epidote; $\mathrm{hbl}=$ hornblende Foto 4 - Epídoto granular (típo IV) ao longo do contato do anfibólio com plagioclásio num encrave quartzo-diorftico no stock cálcio-alcalino de Conceição, Paraíba (CSF). Nicois cruzados e aumento de 63 vezes. $\mathrm{Ep}=$ epídoto; $\mathrm{hbl}=$ hornblenda

subrounded to elongate, unfoliated stocks along the major foliation trend, intruded into all the extension of the CSF. They are granodiorites and tonalites, composed of quartz, oscillatorily zoned plagioclase $\left(\mathrm{Ab}_{63}{ }^{-96}\right)$, microcline $\left(\mathrm{Or}_{71}{ }^{-90}\right)$, hornblende, biotite, epidote (four textural types as described above, being the type III the most common), sphene, apatite and, in some plutons, zircons inside biotite. Opaques are rather rare, often represented by magnetite.

Unfoliated to weakly foliated granitoids of trondhjemitic affinities which intruded amphibolite-facies metasediments of the Salgueiro Group, are regionally known as Serrita-type granitoids. They are leucocratic, biotite and amphibole-bearing tonalites to granodiorites and exhibit quartz, plagioclase $\left(\mathrm{Ab}_{89-94}\right)$, microcline $\left(\mathrm{Or}_{74-93}\right)$, euhedral to subhedral, types III and IV epidote, biotite, primary muscovite (according to textural criteria of Miller et al. 1981), apatite, zircon, titanite and rare opaque minerals. These plutons seem to be a good example of Brasiliano-age primary epidote-bearing trondhjemites.

Large shoshonitic plutons in the CSF (e.g. Teixeira, Solidão, Fig. 1), which lie in the northern prolongation of the syenitoid line (an alignment defined by peralkalic syenites and shoshonitic granitoids along the southern boundary of the CSF), contain type II and type IV igneous epidote.

The presence of igneous epidote was recorded in the main facies of the Brejinho batholith, a porphyritic biotite-monzogranite, located not far from the southern boundary of the CSF. Elongate, mafic enclaves in this batholith are found in swarms, irregularly distributed within the batholith. They probably represent quartz-dioritic magma globules which coexisted with the monzogranite host.

b. The Serido Fold Belt (SFB) The knowledge of epidote-bearing granitoids in the Seridó Fold Belt is much more limited than in the CSF. The major occurrences are listed in Table 1. Among them, the São Rafael and Boi Selado batholiths seem to be most expressive ones. They are located in the central portion of this belt, respectively near São Rafael and Jurucutu towns, state of Rio Grande do Norte.

In the São Rafael batholith, which exhibits contacts with the Jurucutu gneiss and Seridó micaschists, two petrographic facies are present, one porphyritic and one equigranular (Souza \& Sial 1989). The porphyritic facies, quartz-monzonitic to granitic in composition, is characterized by microcline megacrysts without preferential orientation in an equigranular groundmass. Less frequently, this facies is observed in close association with quartz-diorite enclaves which show pillow-like or stromatic structures. Fine-grained, leucocratic, 1-meter wide garnet-bearing dikes are locally observed. Several types of inclusions are present in this facies, including amphibolite fragments, aggregates of biotite and epidote, quartz-diorite inclusions fringed by a thin layer of biotite + epidote, and fragments of basement rocks (micaschist, gneiss and limestone). The biotite + epidote layers or aggregates were perhaps formed through the reaction below (not tested experimentally; eq. 1 ): $\mathrm{Hbl}+\mathrm{Or}$ + An (from plag.) $+\mathrm{FhO} \rightarrow \mathrm{Ep}+\mathrm{Ab}+\mathrm{Bi}+\mathrm{Qz}$ (1).

The equigranular groundmass is constituted by plagioclase, microcline, quartz, biotite, hornblende, epidote, apatite, allanite and rare opaque minerals. Microcline up to $4 \mathrm{~cm}$ long exhibit rows of biotite and plagioclase, while plagioclase is usually oscillatorily zoned, with myrmekitic intergrowth and less frequently synneusis. Sometimes biotite appears included in hornblende. Epidote is the most important accessory phase, often associated with biotite or amphibole (types II, III and IV), common in the porphyritic facies and absent in the nonporphyritic one. Some crystals show embayments penetrated by quartz. Less often, epidote is seen inside microcline or plagioclase. The Boi Selado batholith, mineralogically and texturally similar to the São Rafael rocks is petrographically composed of tonalite to granodiorite, exhibiting weak foliation. Epidote occurs as types III and IV.

A second type of epidote-bearing granitoids in the SFB is found in the Serra da Garganta (not far from Jurucutu), Baixio, Tapera and Serra do Estreito, between Jucurutu and Caicó towns, state of Rio Grande do Norte. Petrographically, these rocks are essentially quartz-diorites to quartz-monzodiorites. Locally, small, angular to subangular amphibolite enclaves surroundend by biotite are present as well as unfoliated, fine-grained, more mafic inclusions. The latter could represent injection of basic magma blebs into the quartz-diorite magma, or cognate inclusions as fragments of the parental magma that fractionated to yield the host magma of these inclusions.

At Serra do Estreito and Serra da Garganta the mineralogical composition comprises plagioclase, pale green amphibole, pyroxene, biotite, $( \pm)$ microcline, quartz, titanite, epidote and apatite. Pyroxene grains are characterized by a large amount of inclusions in their cores and by margins partially transformed into amphibole. Igneous epidote, sometimes twinned without allanite cores (type III), appears rimmed or included in biotite or less often with allanite core. Secondary epidote is also present

At Tapera, however, epidote although present is rare and seem to be restricted to the unfoliated, fine-grained, more mafic enclaves. This rock contains plagioclase, pyroxene, biotite, amphibole, titanite, allanite and Fe-oxide minerals.

A third type of epidote-bearing ignous rocks is represented by epidote-tonalite dikes usually less than 10m-wide, which intruded Jucurutu Fm. metasediments (e.g. Loca, LM Ranch). They contain the largest amount of epidote, which often appears as euhedral to subhedral phenocrysts without allanite core. Other phases in these dikes are plagioclase, biotite, sphene, apatite and secondary muscovite. Epidote is not essentially related to mafic minerals and is a primary phase if the coexisting plagioclase is andesine. Otherwise, it was produced by recrystallization at $\mathrm{Ab}$-Ep-amphibolite P-T conditions on cooling. It is unclear whether amphibole aggregates represent early fractionated phases or amphibolite xenoliths. 
Table 1-Epidote-bearing calc-alkalic granitoids in Northeast Brazil

- Tabela 1 - Granitóides cálcio-alcalinos com epídoto no Nordeste do Brasil

A) Cachoeitrinha-Salgueiro Fold Belt

\begin{tabular}{|c|c|c|c|c|}
\hline Pluton & Locality & Petrography & Epidote & Reference \\
\hline Penaforte stock & $\begin{array}{l}\text { Next to Pengforte town, } \\
\text { Peruapioutud }\end{array}$ & 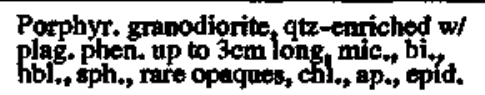 & Type III; wecondary & $1,2,3$ and 4 \\
\hline Tamboril stock & $\begin{array}{l}\text { Next to Verdejante town, } \\
\text { bogudary between the stites } \\
\text { of Paraiba and Pernamburo }\end{array}$ & 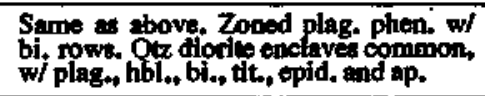 & $\begin{array}{l}\text { Types II, III and IV } \\
\text { (grenutar) around } \\
\text { bictio }\end{array}$ & 1,3 and 5 \\
\hline Matn Boil stock & $\begin{array}{l}\text { About } 30 \mathrm{~km} N W \text { of Serrith } \\
\text { town, state of Permambuco }\end{array}$ & $\begin{array}{l}\text { Same as above w/ plat, phent up to } 4 \\
\text { cm long. Amphibolitat and qt diorito } \\
\text { enclaves common. }\end{array}$ & $\begin{array}{l}\text { Typea II and III } \\
\text { (rane) }\end{array}$ & $1,2,3$ and 4 \\
\hline $\begin{array}{l}\text { Ipueiros-Unubd } \\
\text { small stocks }\end{array}$ & $\begin{array}{l}\text { Next to Ipueiras village, } \\
\text { about } 20 \mathrm{~km} N W \text { of Serrita, } \\
\text { state of Permambuco }\end{array}$ & $\begin{array}{l}\text { Slightly porphyr, grantodiorite to } \\
\text { granity, w/ plag up to } 1 \text { com leng, w/ } \\
\text { amphtibolite and qte dionte onclaves } \\
\text { (pyrt, plag., bi., hbl., epid,, ap.) }\end{array}$ & $\begin{array}{l}\text { Type III; in qtz } \\
\text { diorite enclaves, } \\
\text { type iv }\end{array}$ & $1,2,3$, and 4 \\
\hline Carmo stock & $\begin{array}{l}\text { Next to Carmo town, state of } \\
\text { Pernambic }\end{array}$ & 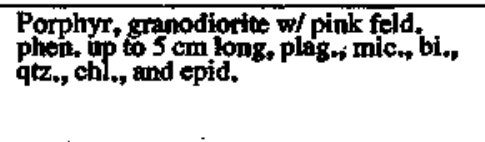 & 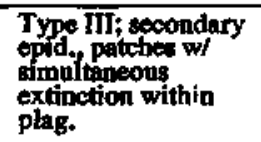 & 2,3 and 7 \\
\hline $\begin{array}{l}\text { Santo Antonio Creok } \\
\text { (Minador) atock }\end{array}$ & $\begin{array}{l}\text { Abont } 30 \mathrm{~km} \text { north of } \\
\text { Serritu town, } \\
\text { Pernatombuco of }\end{array}$ & $\begin{array}{l}\text { Granodtorite w/ mafic enclaves and } \\
\text { composed of plag, mic., qta, allan., } \\
\text { epid, rare opaquen. }\end{array}$ & Type III & 3,4 and 8 \\
\hline $\begin{array}{l}\text { Socorro } \\
\text { Hocks }\end{array}$ & $\begin{array}{l}\text { About } 15 \mathrm{~km} \text { of Pianco } \\
\text { town, state of Paraiba }\end{array}$ & $\begin{array}{l}\text { Tonalite w/ plag. phen., hb1., ttt, epid., } \\
\text { ap. }\end{array}$ & Type II & 12 \\
\hline $\begin{array}{l}\text { Serrote da Cachoeira } \\
\text { stock (Capim Grosso) }\end{array}$ & $\begin{array}{l}10 \mathrm{~km} \text { west of I taporanga } \\
\text { town, state of Paralba }\end{array}$ & Same as above. & Type III & 10 \\
\hline $\begin{array}{l}\text { Erras=Olho D'Agua } \\
\text { batholith }\end{array}$ & $\begin{array}{l}\text { Next to Emas town, state of } \\
\text { Paraliba }\end{array}$ & 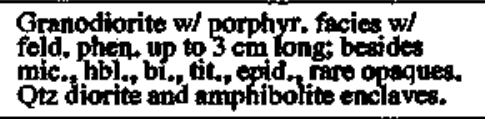 & $\begin{array}{l}\text { Type III; secondary } \\
\text { epidote }\end{array}$ & 3,11 , and 12 . \\
\hline Angico Torto & $\begin{array}{l}\text { About } 10 \mathrm{~km} \text { SE of } \\
\text { Pongtorte between } \\
\text { Verdejante and Penaforte, } \\
\text { state of Pernumbuco }\end{array}$ & $\begin{array}{l}\text { Granodjorite, qtz-euricted w/ plag., } \\
\text { mic, bi, gta, hol, tit, epid, opaque. } \\
\text { Mafic enclaves common. }\end{array}$ & Types I, II and III & $1,2,3$ and 4 \\
\hline Brejiththo batholith & $\begin{array}{l}\text { Next to Brejinitiond and } \\
\text { Itpetim towns, state of } \\
\text { Pernambiceo }\end{array}$ & $\begin{array}{l}\text { Several petrographic facieg; main one } \\
\text { is porphit. bi, mopzogranite wi plag., } \\
\text { mic., hbl., opid,, tit, rano opeques. }\end{array}$ & Type III & 3 and 9 \\
\hline $\begin{array}{l}\text { Verdejanto stacks } \\
\text { (soveral elongato tocks) }\end{array}$ & $\begin{array}{l}\text { Nearby Verdejante town, } \\
\text { gente of Permambuco }\end{array}$ & $\begin{array}{l}\text { Granodiorite w/ plage, mic., bi, qtz, } \\
\text { epdd, \&p, tict }\end{array}$ & Type III (rare) & 2 and 5 \\
\hline $\begin{array}{l}\text { Jandim gatack (pertially } \\
\text { covered by Creasceouts } \\
\text { sediments) }\end{array}$ & $\begin{array}{l}\text { About } 7 \mathrm{~km} \text { cast of Jardim } \\
\text { cown, state of Ceard }\end{array}$ & Same above, Secondary chlorite, & Types I and III & 4 \\
\hline Jati stock & $\begin{array}{l}\text { About } 3 \mathrm{~km} \text { south of Jati, } \\
\text { Roud BR-1 } 6 \text {, state of Cears }\end{array}$ & $\begin{array}{l}\text { Grunodiorite w/plag., mic., qte, bi., } \\
\text { hbl, epid., op. tit. }\end{array}$ & Type III & 4 \\
\hline Conceiç5 atock & $\begin{array}{l}\text { Nexi to Conceiclio town, } \\
\text { Whto of Parafibe }\end{array}$ & $\begin{array}{l}\text { Tonalite of plag, hblo, bi., qtz., tit., } \\
\text { epid, and ap., otz dionts and } \\
\text { amphibolite common. }\end{array}$ & $\begin{array}{l}\text { Type I and ItI; type } \\
\text { IV ln the qtz, diox. } \\
\text { enclaves }\end{array}$ & 2,3, and 5 \\
\hline Boa Ventura stock & $\begin{array}{l}\text { About } 10 \mathrm{~km} \mathrm{SW} \text { of } \\
\text { Itaporanga, ateip of Paralba }\end{array}$ & $\begin{array}{l}\text { Tormilite w/ plag., hbl., bi., qtz, epid., } \\
\text { ap, bt. }\end{array}$ & Type III & 10 \\
\hline \multirow[t]{2}{*}{ Inesgoplis stock } & 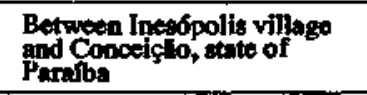 & $\begin{array}{l}\text { Tonalite w/ plag, hblotic, qka, epid," } \\
\text { rane opeques, Amphibolite enclaved. }\end{array}$ & Type I & 5; thite work \\
\hline & & B) Seridd Fold Bett (SFB) & & \\
\hline Sto Rofacl batholith & $\begin{array}{l}\text { Eust of Sto Rafagl town } \\
\text { state of Rio Grande do Norte }\end{array}$ & 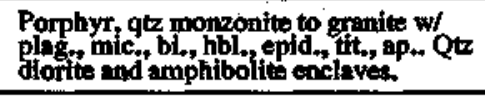 & Type II, III and IV & 3 and 14 \\
\hline $\begin{array}{l}\text { Serra da Garganta } \\
\text { batholith }\end{array}$ & $\begin{array}{l}\text { About } 15 \mathrm{~km} \text { eat of } \\
\text { Jucuntal , state of Rio } \\
\text { Grande do Norte }\end{array}$ & 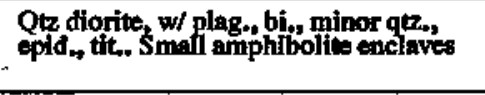 & Type III & This work \\
\hline Bof Selado batholith & 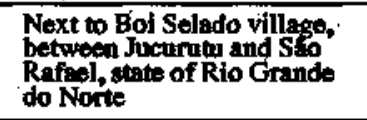 & 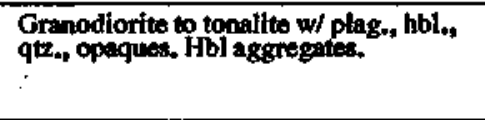 & $\begin{array}{l}\text { Types III and } \\
\text { secodiary epid. }\end{array}$ & Thts work \\
\hline Catole do Rocha & $\begin{array}{l}4 \text { Km eagt of Casolf do } \\
\text { Rocha, roed to Brejo do } \\
\text { Cruz, state of Paralba }\end{array}$ & $\begin{array}{l}\text { Gramodiontio w/ plag. (myrmektio), } \\
\text { mic., bi, thit, epid, zoned allan, mit., } \\
\text { ap., secondary muscovite. }\end{array}$ & Typo III & 14; this work \\
\hline Brejo to Cruz & $\begin{array}{l}\text { At Brejo do Cruz town, stato } \\
\text { of Parfifat }\end{array}$ & 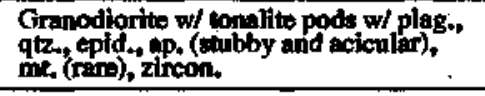 & Typo III & 14; this work \\
\hline Serra Negra do Norte & 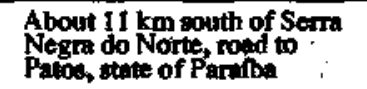 & 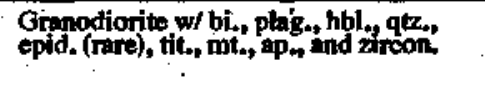 & Type III & 15; this work \\
\hline
\end{tabular}


Table 1. Continued

\begin{tabular}{|c|c|c|c|c|}
\hline Ploton & Locallity & Petrography & Epidote typ: & Referionces \\
\hline $\begin{array}{l}\text { Serm do Estreito } \\
\text { bitholith }\end{array}$ & $\begin{array}{l}\text { Next to Laginhe village } \\
\text { between Caco and Jucurutu, } \\
\text { Rio Grande do Norte }\end{array}$ & $\begin{array}{l}\text { Tomalite to granodiocite w/ pligen hble, } \\
\text { bi, qtz, mic, epid, ap. }\end{array}$ & $\begin{array}{l}\text { Type III; secondary } \\
\text { epid. }\end{array}$ & This work \\
\hline Baixio block & $\begin{array}{l}\text { About } 29 \mathrm{~km} \text { north of Crico } \\
\text { town, Rio Girnde do Norte }\end{array}$ & 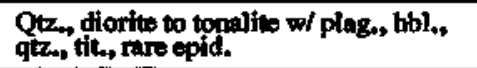 & Type III & This work \\
\hline Patu batholith & $\begin{array}{l}\text { Next to Patg town, Rio } \\
\text { Grande do Norte }\end{array}$ & 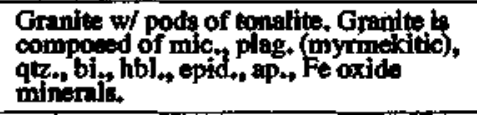 & Type III & 14; this work \\
\hline Lock dike & 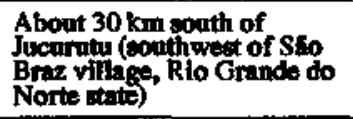 & $\begin{array}{l}\text { Medium to fine-grainod opid, tonalite } \\
\text { w/ qtz, plag, epid., tite, ape, sor. }\end{array}$ & $\begin{array}{l}\text { Type गI (phen., } \\
\text { symplectitic) }\end{array}$ & This work \\
\hline Cachooirn (Tapera atock) & $\begin{array}{l}\text { Abour } 10 \mathrm{~km} \text { south of } \\
\text { Jucurtutu town, dtatie of Rio } \\
\text { Grande do Norte }\end{array}$ & 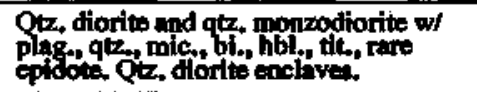 & Type II (rare) & This work \\
\hline LM Ranch dike . : & $\begin{array}{l}\text { At the rond Citco-Jurucuth, } \\
\text { next to Laginhe village, athe } \\
\text { of Rio Grande do Noive }\end{array}$ & $\begin{array}{l}\text { Qtz diorite to epid, tonnlite w/ plag, } \\
q(z, \text {, bi., hbl, tit, epid. }\end{array}$ & $\begin{array}{l}\text { Type III (phon. } \\
\text { symplectidc) }\end{array}$ & This wodk \\
\hline \multicolumn{5}{|c|}{ C) Riacho do Pontal Fold Belt (RPFB) } \\
\hline Tigre atrocka & $\begin{array}{l}\text { About } 23 \mathrm{~km} \text { went of Tigre, } \\
\text { gtale of Pianf }\end{array}$ & $\begin{array}{l}\text { Porphyr, granodionfite to granite, } \\
\text { qtz,-entiched, similar to the Tamboril } \\
\text { stock, Pernembuco, wi mic, phen., } \\
\text { plag,, bi., epid., tit. }\end{array}$ & Tyре III & This wodk \\
\hline Barra do Marinho stock & $\begin{array}{l}\text { Abount } 5 \mathrm{~km} \text { northwogt of } \\
\text { Monte Oreb, state of Pinut }\end{array}$ & 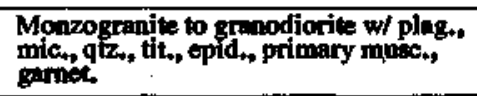 & Type III & 16; this work \\
\hline \multicolumn{5}{|c|}{ D) Sergipean Fold Belt } \\
\hline Loindes Sinck & $\begin{array}{l}\text { North of Luities, state of } \\
\text { Sergipe }\end{array}$ & $\begin{array}{l}\text { Tonalite to granodiortic w/ qtz., plage, } \\
\text { mic., bi., misc., opid., rafe opeques. }\end{array}$ & Type III & $\begin{array}{l}\text { I. M. Rangei, } \\
\text { percining } \\
\text { communication, } \\
\text { 1990. }\end{array}$ \\
\hline \multicolumn{5}{|c|}{ E) Pajen-Paraibat Fold Belt (PPPB) } \\
\hline Quitimbu stock & $\begin{array}{l}\text { Neir Afogados da Ingravir. } \\
\text { sthe }\end{array}$ & $\begin{array}{l}\text { Qtz, diorite w/ plag, bi., qta., } \\
\text { epid., ap. }\end{array}$ & Type III & 17; this wort \\
\hline Afogados da Ingazeira & $\begin{array}{l}\text { Around Afogados da } \\
\text { Ingareira, state of } \\
\text { Peraumbuco }\end{array}$ & 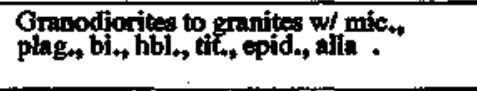 & Type III & 19 \\
\hline \multicolumn{5}{|c|}{ F) Taqunritinga do Norte region (Surabin-Caroalina Complex of Brito Neves, 1983) } \\
\hline Jerimun dike & $\begin{array}{l}\text { Jerimum Ranch about } 28 \mathrm{~km} \\
\text { gorth of Santa Cruz do } \\
\text { Capibaribe, state of } \\
\text { Pernambuc }\end{array}$ & $\begin{array}{l}\text { Medium to finc-ganiped epid. tonalite, } \\
\text { w/ olige, bi, qtz., eplad, socondary } \\
\text { musc., chlor. }\end{array}$ & Type III & 19 \\
\hline Boa Vista dike & $\begin{array}{l}\text { Boa Vida Ranch at about } 30 \\
\text { km north of Santa Cruz do } \\
\text { Capibaribe, fate of } \\
\text { Perambuco }\end{array}$ & Shine as above & Туре III & 19 \\
\hline
\end{tabular}

Abreviations:

Phen. (phenocryst), porphyr. (porphyritic), plag. (plagioclase), bi. (biotite), hbl. (hornblende), tit. (titanite), epid. (epidote), muse, (muscovite), ser. (seriate), ap. (apatite), chl. (chlorite), mt. (magnetite), pyr. (pyroxene), feld. (feldspar).

References: 1. Sial et al. (1981); 2. Sial (1984); 3. Sial (1986); 4. Jardim Map Sheet, CPRM (1983); 5. São José do Belmonte Map Sheet. CPRM (1983); 6. Bodoco Map Sheet, CPRM H983); 7. Feitosa (1982); 8. Caldasso (1964I; 9. Sial \& Ferreira (1990): 10. Itaporanga Map Sheet, CPRM (1983): 11. Goist (1989); 12. Pianco Map Sheet, CPRM (1983); 13. Souza \& Sial (1989); 14. Sial \& Ferreira (1989); 15. Jardim de Sá et al. (1981); 16. Santa Filomena Map Sheet, DNPM (1990); 17. Afogados da Ingazeira Map Sheet, DNPM (1990); 18. Menor\& Sial'(1969); 19. Sial \& Menor (1969)

Besides these three major types of occurrences, igneous epidote has been locally observed in other plutons in the SFB (e.g. Patu, Brejo do Cruz, and east of Catolé do Rocha, state of Paraíba). In the Brejo do Cruz batholith (an equigranular, unfoliated to weakly foliated granite), pods of tonalite are composed of plagioclase, quartz, biotite, amphibole, epidote, titanite, apatite, zircon and rare Fe-oxide minerals. Epidote phenocrysts with allanite core, within biotite, are common. Stubby to acicular apatite is very common suggesting that the tonalite pods represent injection of hotter tonalite magma into a cooler granite host. At Patu, a similar situation is observed, where more mafic patchy inclusions, one or two-meter wide, are found in a granite host. In this place, structures suggest the coexistence of two magmas of contrasting compositions and three generations of mafic, igneous inclusions have been detected (pre to post-intrusion of the granite host). Texturally and mineralogically, these enclaves resemble the tonalite enclaves at Brejo do Cruz batholith.

Finally, about $3 \mathrm{~km}$ east of Catolé do Rocha, along the road to Brejo do Cruz, a small granodiorite stock, texturally similar to the Conceição-type granitoids of the CSF, exhibits rare crystals of type $\mathrm{HI}$ epidote, zoned allanite, magnetite, apatite, titanite and secondary muscovite.

c. The Riacho do Pontal Fold Belt (RPF) Granitoids in this Fold Belt are much less known than those in the other two segments of the CSD. At present only two occurrences of epidote-bearing granitoids have been identified. One is represented by small stocks about $23 \mathrm{~km}$ west of Tigre Village, and the other one is represented by Barra dó Marinho stock about $5 \mathrm{~km}$ nortwest of Monte Oreb, both in the state of Piauí. 
The stocks near Tigre are porphyritic granodiorite to granite, quartz-enriched, similar to some of the stocks in the CSF. They are composed of microcline phenocrysts, plagioclase, biotite, epidote and sphene. Igneous, euhedral to subhedral epidote is found within plagioclase or mica, rimmed by biotite with or without allanite core. These rocks show a slight deformation and, in some places, lens-shaped microcline phenocrysts.

The Barra do Marinho stock composed of a porphyritic monzogranite to granodiorite, locally sheared in its eastern portion (e.g. Lagoa Salgada Ranch), with quartz ribbons and slightly rotated pink alkali-feldspar, intruded tonalites to granites and metasediments of the Casa Nova Complex (Angelim 1988). Its mineralogy differs from that of the other epidote-bearing plutons described above in that it contains garnet and primary muscovite. Euhedral to subhedral epidote is found rimmed by biotite with or without allanite core. Texturally, this mineral looks like an igneous phase, but as these rocks underwent some shearing, it could have grown during the shear event.

d. Epidote-bearing granitoids outside the CSD The occurrence of epidote-bearing granitoids have been observed outside the central structural domain. In some granodiorite to granite stocks near Afogados da Ingazeira and in a quartz diorite near Quitimbu (Pajeú-Paraíba Fold Belt), state of Pernambuco, Menor \& Sial (1969) described epidote inside biotite. At Jerimum and Boa Vista Ranches, next to Santa Cruz do Capibaribe town, state of Pernambuco, medium to fine-grained, equigranular epidote-tonalite dikes, $5 \mathrm{~m}$ to $10 \mathrm{~m}$ wide, intruded regional migmatites. They are equigranular, medium to fine-grained rocks and contain oligoclase, biotite, plagioclase, quartz, epidote, zircon, magnetite and secondary chlorite and muscovite. At Quixadá, state of Ceará, Silva (1989) described igneous epidote in diorite to quartz-diorite enclaves in the porphyritic, monzonitic to quartz-monzonitic Quixadá batholith. Epidote appears as euhedral to subhedral crystals included in biotite. Finally, about $20 \mathrm{~km}$ north of Lurdes, Sergipe, some two mica granodiorites to tonalites that intruded low-grade metasediments of the Sergipean Fold Belt contain igneous epidote, usually rimmed by biotite (J. M. Rangel, personnal communication, 1990).

e. Modal compositions Modal compositions for the CSF epidote-bearing granitoids once plotted in the QAP diagram (Streckeisen 1973) display one trend in the tonalite and granodiorite fields with two major distinct clusters (Fig. 2). The SFB epidote-bearing granitoids delineate two parallel trends distinct form the CSF one. One of them lies in the monzodiorite and tonalite fields and two samples from the CSF along this trend in the granite field. The other trend lies in the monzonite and granite fields. The trends in the SFB are more potassic than the CSF one.

GEOCHEMISTRY a. Major and trace chemistry: epidote-bearing granitoids in the CSF are tipically calc-alkalic as recognized by Sial (1984). Twenty seven representative analyses are available and indicate that in these rocks $\mathrm{SiCh}$ varies from $56 \%$ to $71 \%$ with $\mathrm{Al}_{2} \mathrm{O}_{3}$ around $15 \%, \mathrm{Na}_{2} \mathrm{O}>$ $\mathrm{K}_{2} \mathrm{O}$ with some exceptions, and $\mathrm{MgO}$ varying from $0.4 \%$ to $4 \%$. Most of these plutons is peraluminous (Fig. 3), except the Emas batholith (Goist 1989) which is peraluminous to metaluminous.

All geochemical groups of granitoids in the CSF are $\mathrm{Sr}$ and Ba-enriched (Sial 1987). The epidote-bearing granitoids, however, show moderate $\mathrm{Sr}(250 \mathrm{ppm}-500 \mathrm{ppm})$, are slightly Ba-enriched (650 ppm - $1500 \mathrm{ppm})$, with intermediate $\mathrm{Zr}(=180 \mathrm{ppm})$ and low $\mathrm{Nb}(<20 \mathrm{ppm})$. They are enriched in REE relative to chondrite abundances, depleted in HREE relative to LREE (Fig. 4) and display a

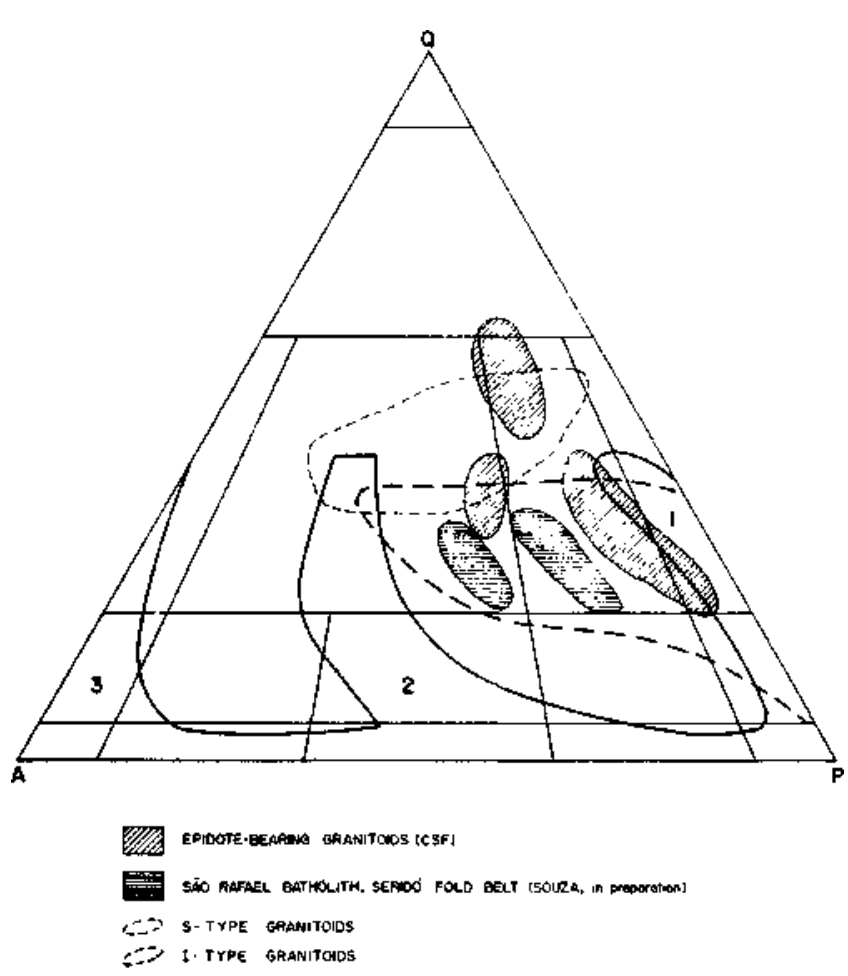

Figure 2 - QAP ternary plot for epidote-bearing calc-alkalic granitoids of the Conceição-type (CSF) and for the São Rafael batholith in the Seridó Fold Belt. Trends 1. calc-alkalic trondhjemitic (low K), 2. calc-alkalic monzonitic (high K) and 3. alkalic to peralkalic, are from Lameyre \& Bowden (1982). Typical areas for $S$ and I-type granitoids are from Loiselle \& Wones(1979)

Figura 2 - Diagrama QAP para granitóides cálcio-alcalinos do tipo Conceição (CSF) e para o batólito de São Rafael no Seridó. Trends 1. trondhjemítíco cálcio-alcalino (baixo K), 2. monzonítico cálcioalcalino (alto K) e 3. alcalino a peralcalino são de Lameyre \& Bowden (1982). Áreas típicas para granitóides dos tipos I e S são de Loiselle \& Wones(1979)

variable negative $\mathrm{Eu}$ anomaly $\left(\mathrm{Eu} / \mathrm{Eu}^{*}\right.$ varies from 0.75 to 0.90 ) and total REE from $116 \mathrm{ppm}$ to $166 \mathrm{ppm}$. These patterns are compatible with combined fractionation of amphibole and plagioclase.

Preliminary bulk chemical composition for the epidote-bearing facies of the São Rafael batholith, in the SFB, indicates $\mathrm{SiO}_{2}$ around $70 \%, \mathrm{~K}_{2} \mathrm{O}$ between $2.5 \%-3.5 \%$, $\mathrm{Na}_{2} \mathrm{O}$ between $4 \%-5 \%$ and $\mathrm{MgO}$ around $1 \%$. This facies is slightly more enriched in $\mathrm{Sr}(600 \mathrm{ppm}-1000 \mathrm{ppm})$ than the epidote-bearing granitoids in the CSF, and with $\mathrm{Ba}$ in an equivalent range to those in th CSF. $\mathrm{Zr}$ is found at intermediate values $(\cong 250 \mathrm{ppm})$ while $\mathrm{Nb}$ is rather low (= $20 \mathrm{ppm}$ ). They are LREE-enriched and HREE-depleted (Fig. 4) in relation to chondrite abundances, and lacking or showing a negligible Eu anomaly. These patterns differ from those in the epidote-bearing granitoids of the CSF, in consonance with the hypothesis that they belong to two distinct suites.

In the RPF, epidote-bearing granitoids (e.g. Tigre and Afrânio stocks) display Sr (120 ppm - 450 ppm), Ba (610 ppm - 1280 ppm), Zr (310 ppm - 330 ppm) and Nb (28 ppm - 36 $\mathrm{ppm}$ ) contents not too different from those in the CSF granitoids. They display REE patterns with negative slope, lacking or with discrete, negative Eu anomaly.

b. Oxygen isotopes: A certain number of oxygen isotope compositions have been determined for the calc-alkalic, 

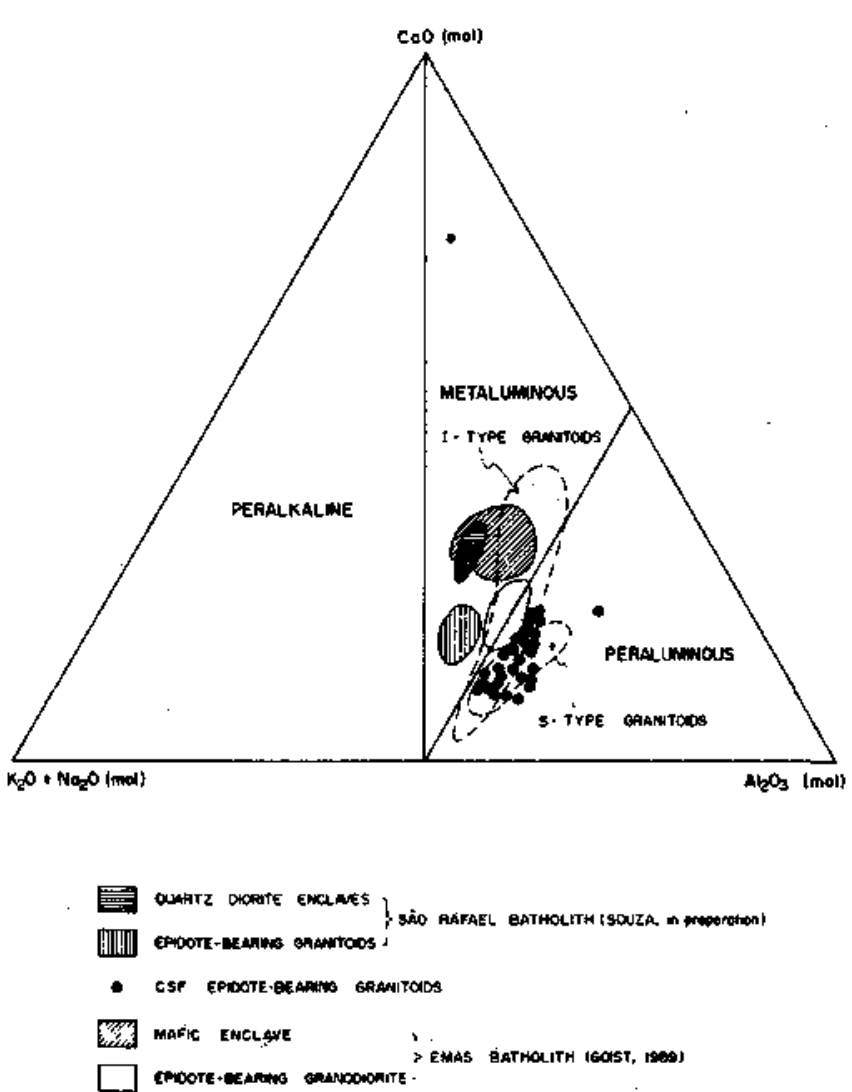

Figure 3 - Alkalis-CaO- $\mathrm{Al}_{2} \mathrm{O}_{3}$ ternary plot (Loiseüe \& Wanes, 1979) for epidote-bearing granitoids in the CSF and for the São Rafael batholith in the Serido Fold Belt Figura 3 - Diagrama temário Álcalis-CaO- $\mathrm{Al}_{2} \mathrm{O}_{3}$ (Looiselle \& Wooes 1979) para granitóides com epídoto no CSF e para o batólito de São Rafael no Seridò

epidote-bearing granitoids in the CSF as well as for some representative granitic plutons within the SFB. Besides, five representative epidote-bearing rocks from Idaho, USA, were analysed for comparison.

Technique and standards Oxygen extractions were performed by reaction with fluorine at the Department of Geology of the University of Georgia at Athens, USA. Isotopic analyses were made using a Finnigan Mat Delta E triple collector, dual inlet mass spectrometer. Routine intercomparisons of samples with rose quartz standard were made, the standard defined as +8.45 permil relative to SMOW.

Whole-rock oxygen isotope data In analysing oxygen isotopes, the primary interest was to determine the regional oxygen isotope patterns, and therefore no attempt to interpret the isotopic variations within a pluton was made. Most plutons analysed were probably emplaced at depths around or greater than $20 \mathrm{~km}$, and this limits the possibility of interaction with meteoric water, although it cannot be excluded.

Forty whole-rock $\delta^{18} \mathrm{O}$ analyses from nine epidote-bearing granitoids in the CSF compared to SMOW are found in table 2. Besides, one representative sample from the Cachoeirinha Group, one from the Salgueiro Group metasediments and one from the basement gneisses were analysed. The first one yielded a $\delta^{18} \mathrm{O}$ value +12.5 permil, while the Salgueiro schists, +13.5 permil and the

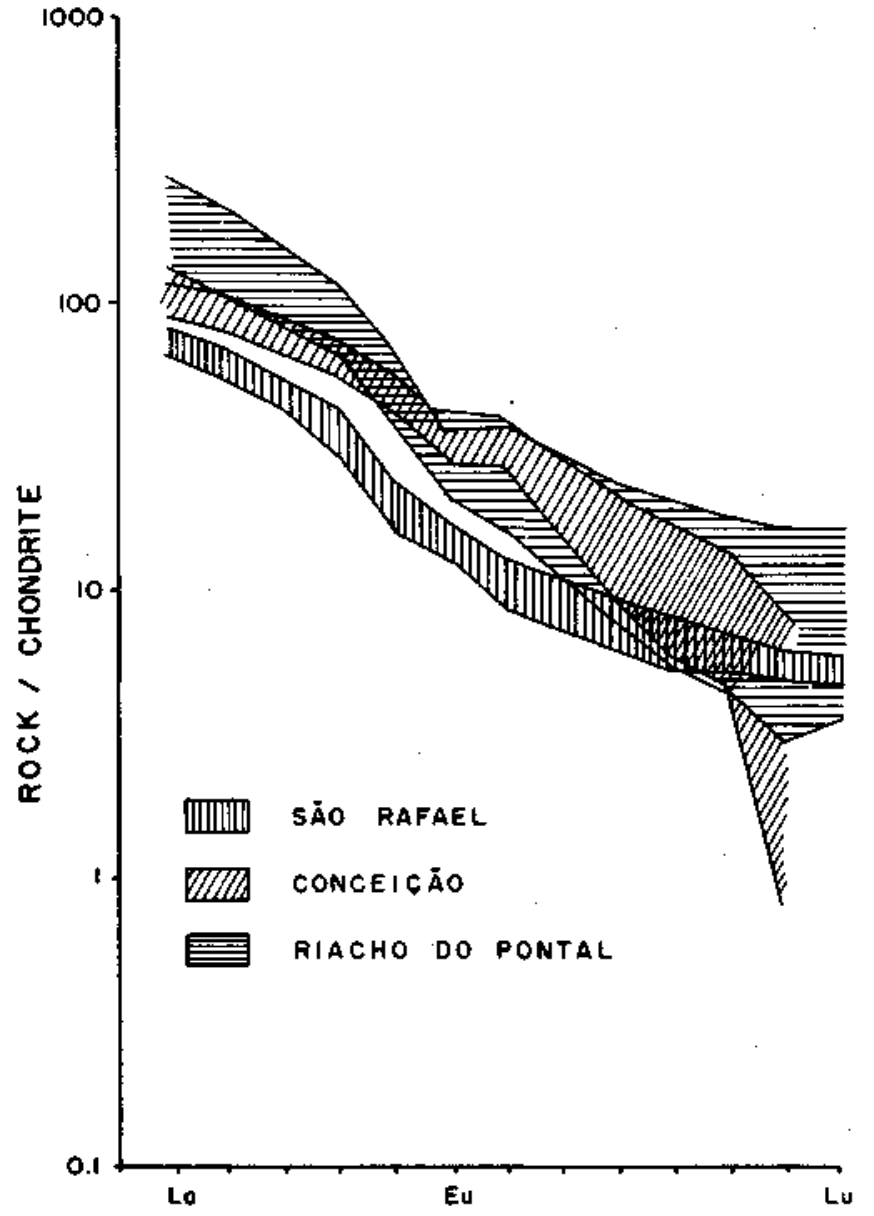

Figure 4 - Chondrite-normaüzed REE-patterns for epidote-bearing granitoids in the Cachoeirinha-Salgueiro and Riacho do Pontal Fold Belts and for the São Rafael pluton in the Seridó $F$ did Belt (see text for explanation) Figura 4 - Padrões de terras raras normalizados para o condrito para granitóides nos cinturões Cachoeirinha-Salgueiro e Riacho do Pontal e para o plutão de São Rafael no Seridó (consultar o texto para explicação)

Cachoeirinha phyllites, +16.0 permil.

All plutons for which five or more samples were analysed exhibit a total range of $\delta^{18} \mathrm{O}$ values of less than 2 permil $_{\text {SMOW. }}$ Values for eight plutons spread along $150 \mathrm{~km}$ within the CSF are greater than +11 permil, most of them between 12 permil - 13 permil.

Sial \& Ferreira (1990) recognized an apparent correlation between $\delta^{18} \mathrm{O}$ of the several groups of granitoids in the CSF and grade of metamorphism of the host rock, increasing from those which intruded gneiss-migmatite of the basement (K-calc-alkalic, shoshonitic and saturated peralkalic) to those which intruded phyllites of the Cachoeirinha Group (epidote-bearing calc-alkalic group).

However, interaction with high ${ }^{18} \mathrm{O}$ country rocks was not responsible for the high values observed in the epidote-bearing, calc-alkalic granitoids. This statement is based on the fact that the epidote-bearing Brejinho batholith, which intruded migmatites of the basement, exhibits an average whole-rock $\delta^{18} \mathrm{O}$ of +11.2 permil and therefore the much higher $\delta^{18} \mathrm{O}$ values of these rocks are not directly related to the grade of metamorphism of the host rocks. This contention is reinforced by the fact that peralkalic dikes, very narrow and therefore susceptible to interaction with wall-rocks, exhibit $\delta^{18} \mathrm{O}$ values not too different when they 
Table 2 - Oxygen isotope composition of epidote-bearing calc-alkalic rocks in the Central Structural Domain, Northeast Brazil and Northwestern USA

Tabela 2 - Composição de isotopes de oxigênio de rochas cálcio-alcalinos com epidoto no domínio estrutural central, Nordeste do Brasil e Nordeste dos Estados Unidos

A) Chachoeirinha-Salgueiro Fold Belt (CSF)

\begin{tabular}{|c|c|c|c|c|c|c|c|}
\hline Sample & Rock type & W.R. $\delta^{18} \mathrm{O}$ & $\mathrm{Qz}$ & Feld, & Biot. & Epid. & Pluton \\
\hline $\begin{array}{l}\mathrm{C}-1 \\
\mathrm{C}-2\end{array}$ & $\begin{array}{l}\text { Tonalite } \\
\text { Tonalite }\end{array}$ & $\begin{array}{l}+11.5 \\
+11.6\end{array}$ & $\begin{array}{c}+13.6 \\
-\end{array}$ & $\begin{array}{c}+12.3 \\
-\end{array}$ & $\begin{array}{c}+9.1 \\
-\end{array}$ & $=$ & Conceiçấo stock \\
\hline $\mathrm{I}-01$ & Tonalite & +12.8 & - & - & $=$ & - & Serrote da Cachoeira \\
\hline $\begin{array}{l}\text { SER-46 } \\
\text { SER-47 } \\
\text { SER-49 } \\
\end{array}$ & $\begin{array}{l}\text { Granodiorite } \\
\text { Granodiorite } \\
\text { Granodiorite } \\
\end{array}$ & $\begin{array}{l}+11.8 \\
+12.4 \\
+12.4 \\
\end{array}$ & $\begin{array}{r}\overline{-} \\
+\overline{13} .1 \\
\end{array}$ & $\begin{array}{r}\overline{-} \\
+\overline{11.5} \\
\end{array}$ & $\begin{array}{c}\overline{-} \\
+\overline{8} .9\end{array}$ & $\begin{array}{l}\bar{z} \\
\bar{z}\end{array}$ & $\begin{array}{l}\text { Santo António Creek } \\
\text { (Minador) }\end{array}$ \\
\hline $\begin{array}{l}\text { SER-81 } \\
\text { SER-82 } \\
\text { SER-83 }\end{array}$ & $\begin{array}{l}\text { Granodiorite } \\
\text { Granodiorite } \\
\text { Granodiorite }\end{array}$ & $\begin{array}{l}+12.1 \\
+12.9 \\
+12.8\end{array}$ & $\begin{array}{l}- \\
-\end{array}$ & $\begin{array}{l}- \\
-\end{array}$ & $\begin{array}{l}- \\
=\end{array}$ & $\begin{array}{l}- \\
\overline{-}\end{array}$ & Ipueiras small stocks \\
\hline $\begin{array}{l}\text { SER-70 } \\
\text { SER-71 } \\
\text { SER-77 } \\
\text { SER-79 } \\
\text { SER-80 }\end{array}$ & $\begin{array}{l}\text { Granodiorite } \\
\text { Granodiorite } \\
\text { Granodiorite } \\
\text { Granodiorite } \\
\text { Granodiorite }\end{array}$ & $\begin{array}{l}+11.5 \\
+12.6 \\
+11.2 \\
+12.8 \\
+12.6 \\
\end{array}$ & $\begin{array}{l}- \\
- \\
- \\
-\end{array}$ & $\begin{array}{l}- \\
- \\
\overline{-} \\
=\end{array}$ & $\begin{array}{l}\overline{-} \\
\bar{z} \\
\bar{z}\end{array}$ & $\begin{array}{l}= \\
\overline{-} \\
= \\
=\end{array}$ & Penaforte stock \\
\hline $\begin{array}{l}\text { SER-37 } \\
\text { SER-39 } \\
\text { SER-40 } \\
\text { SER-52 } \\
\end{array}$ & $\begin{array}{l}\text { Granodiorite } \\
\text { Granodiorite } \\
\text { Granodiorite } \\
\text { Granodiorite }\end{array}$ & $\begin{array}{l}+11.2 \\
+12.3 \\
+12.8 \\
+12.2 \\
\end{array}$ & $\begin{array}{l}\bar{z} \\
- \\
- \\
\end{array}$ & $\begin{array}{l}- \\
\overline{-} \\
\bar{z}\end{array}$ & $\begin{array}{l}\overline{-} \\
- \\
-\end{array}$ & $\begin{array}{l}- \\
- \\
-\end{array}$ & $\begin{array}{l}\text { Small stocks } 20 \mathrm{~km} \\
\text { north of Serrita }\end{array}$ \\
\hline $\begin{array}{l}5-82-53 \\
15-82-107 \\
\end{array}$ & $\begin{array}{l}\text { Granodiorite } \\
\text { Granodiorite } \\
\end{array}$ & $\begin{array}{l}+12.7 \\
+12.9 \\
\end{array}$ & $=$ & $=$ & $=$ & $\begin{array}{l}- \\
-\end{array}$ & Carmo stock \\
\hline $\begin{array}{l}\text { TIM } 03 \\
\text { ITIM } 11 \\
\text { ITIM } 14 \\
\text { ITIM } 21 \\
\text { ITIM } 30 \\
\text { ITIM } 40 \\
\text { ITIM } 50\end{array}$ & $\begin{array}{l}\text { Bi-monzogranite } \\
\text { Bi-monzogranite } \\
\text { Bi-monzogranite } \\
\text { Bj-moniogranite } \\
\text { Bi-monzogranite } \\
\text { Bi-monzogranite } \\
\text { Bj-monzogranite }\end{array}$ & $\begin{array}{l}+10.5 \\
+12.0 \\
+10.8 \\
+11.6 \\
+10.9 \\
+11.1 \\
+11.6\end{array}$ & $\begin{array}{l}+12.6 \\
+12.0 \\
= \\
= \\
=\end{array}$ & $\begin{array}{l}+10.9 \\
+11.9 \\
= \\
= \\
=\end{array}$ & $\begin{array}{l}+7.9 \\
+7.3 \\
= \\
= \\
-\end{array}$ & $\begin{array}{l}= \\
= \\
= \\
=\end{array}$ & Brejinho batholith \\
\hline $\begin{array}{l}E-2 \\
E-15 \\
E-20 \\
E-31 \\
E-36 \\
E-47 \\
E-62 \\
E-80 \\
E-92 \\
E-104 \\
E-110 \\
E-113 \\
E-119\end{array}$ & $\begin{array}{l}\text { Granodiorite } \\
\text { Granodiorite } \\
\text { Granodiorite } \\
\text { Hbl-rich enclave } \\
\text { Granodiorite } \\
\text { Granodiorite } \\
\text { Granodiorite } \\
\text { Granodiorite } \\
\text { Granodiorite } \\
\text { Granodiorite } \\
\text { Granodiorite } \\
\text { Granodiorite } \\
\text { Granodiorite }\end{array}$ & $\begin{array}{l}+11.4 \\
+11.6 \\
+11.9 \\
+10.5 \\
+11.8 \\
+11.1 \\
+11.2 \\
+12.4 \\
+11.4 \\
+11.6 \\
+11.9 \\
+11.2 \\
+11.6\end{array}$ & $\begin{array}{l}+\overline{13.7} \\
- \\
= \\
\overline{-} \\
+\overline{13.9} \\
+14.1 \\
+\overline{15.9} \\
+\overline{13.9} \\
-\end{array}$ & $\begin{array}{c}+\overline{11.5} \\
\overline{-} \\
\overline{-} \\
+\overline{11.5} \\
+12.3 \\
+\overline{11.8} \\
+\overline{11.6} \\
-\end{array}$ & $\begin{array}{c}- \\
+8.4 \\
= \\
= \\
\overline{-} \\
+8.0 \\
+10.1 \\
+8.9 \\
+8.4 \\
+\end{array}$ & $\begin{array}{l}+\overline{9.7} \\
= \\
= \\
= \\
= \\
+\overline{9} .4 \\
= \\
=\end{array}$ & $\begin{array}{l}\text { Emas-Olho D'Agua } \\
\text { batholith (Goist I989) }\end{array}$ \\
\hline \multicolumn{8}{|c|}{ B) Serid6 Fold Belt (SFB) } \\
\hline SNN-2 & Granodiorile & +6.2 & - & - & - & - & Serra Negra do Norte \\
\hline $\begin{array}{l}\text { SR-2 } \\
\text { SR-3 } \\
\text { SR-4 } \\
\end{array}$ & $\begin{array}{l}\text { Qtz monzonite } \\
\text { Qtz monzonite } \\
\text { Qtz monzonite }\end{array}$ & $\begin{array}{l}+7.9 \\
+7.8 \\
+8.1 \\
\end{array}$ & $\begin{array}{l}\overline{-} \\
z\end{array}$ & $\begin{array}{l}\bar{z} \\
\bar{z}\end{array}$ & $\begin{array}{l}\bar{z} \\
\bar{z}\end{array}$ & $\begin{array}{l}- \\
\bar{z}\end{array}$ & Sáo Rafael batholith \\
\hline BAX-1 & Qtz diorite & +7.8 & - & - & - & - & Baixio sotck \\
\hline \multicolumn{8}{|c|}{ C) Idaho phutons, Northwestem USA } \\
\hline Sample & Rock type & W.R. $8^{16} \mathrm{O}$ & $Q_{2}$ & & $2 z$-corrected & & eference \\
\hline $\begin{array}{l}6-17-84-4 C \\
6-17-84-7 A \\
6-17-84-4 A \\
6-17-84-5 A \\
6-17-84-4 B \\
\end{array}$ & $\begin{array}{l}\text { Tonalite } \\
\text { Tonalite } \\
\text { Epid. tonalite } \\
\text { Epid. tonalite } \\
\text { Leucotonalite } \\
\end{array}$ & $\begin{array}{r}+11.1 \\
+7.7 \\
+8.0 \\
+7.4 \\
+8.9 \\
\end{array}$ & $\begin{array}{r}+10.0 \\
+10.4 \\
+9.7 \\
+8.7 \\
+10.3 \\
\end{array}$ & & $\begin{array}{l}+8.8 \\
+9.2 \\
+8.5 \\
+7.5 \\
+9.1 \\
\end{array}$ & & $\begin{array}{l}\text { aho epidote-bearing } \\
\text { utons collected by } \\
\text { An Zen }\end{array}$ \\
\hline $\begin{array}{l}83 Z 1 \\
83 Z 2 \\
83 Z 9 \\
85 Z 11 \\
85 Z 17-d i k e\end{array}$ & $\begin{array}{l}\text { Epid. tonalite } \\
\text { Epid. tonalite } \\
\text { Epid. tonalite } \\
\text { Epid. tonalite } \\
\text { Epid. tonalite }\end{array}$ & $\begin{array}{r}+8.4 \\
+7.9 \\
+7.9 \\
+7.6 \\
+10.0\end{array}$ & $\begin{array}{l}= \\
= \\
=\end{array}$ & & $\begin{array}{l}\bar{z} \\
\bar{z}\end{array}$ & & $\begin{array}{l}\text { azard Creek Complex, } \\
\text { aho USA (Manduca } \\
88 \text { ) }\end{array}$ \\
\hline
\end{tabular}

Abbreviations: Qz (quartz), W.R. (whole-rock), Feld (feldspar), Biot. (biotite) and Epid. (epidote). 
intrude Cachoeirinha phyllites or Salgueiro schists. Besides, the widespread amphibolite xenoliths in these calc-alkalic granitoids display $\delta^{18} \mathrm{O}$ around +10.5 permil (e.g. Emas batholith, Goist 1989), and perhaps ${ }^{*} \mathrm{O}$-enriched source rocks are implied.

The epidote-bearing trondhjemitic and shoshonitic granitoids of the CSF display much lower $\delta^{18} \mathrm{O}$ values, between +8 and +10 permil (Sial \& Ferreira 1990).

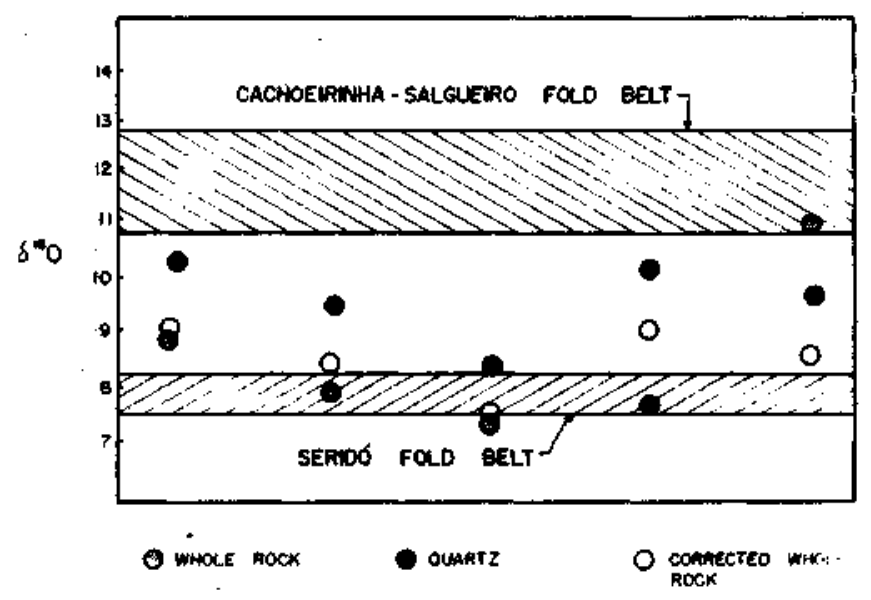

Hgure $5-\delta^{18} O$ variation for epidote-bearing granitoids of the Hazard Creek Complex, Idaho, USA. $\delta^{18} \mathrm{O}$ range for granitoids in the CSF and in the Serido Fold Belt are shown for comparison

Figura 5 - Variação de $\delta^{18} \mathrm{O}$ para granitóides com epídoto do Complexo Hazard Creek, Idaho, Estados Unidos. As variações de $\delta^{18} \mathrm{O}$ para granitóides no CSF e no Seridò são mostradas para comparação

Sixteen samples of granitoids from the SFB were analysed. Among those, three epidote-bearing calc-alkalic granitoids (São Rafael, Baixio) and a pluton, next to Serra Negra do Norte; (Tab. 2) are much less $1^{\circ} \mathrm{O}$-enriched $(+6.2$ permil to +8.1 permil) than petrographically equivalent plutons in the CSF. Judging from feldspars and micas in these rocks (e.g. São Rafael) they did not seem to have suffered an important secondary alteration.

For epidote-bearing tonalites in Idaho, Northwestern North America, provided by Zen (1985) and analysed for comparison, values between +7.5 permil and +9.2 permil were found (Tab. 2), similar to values listed by Manduca et ai. (1989) for the Hazard Creek Complex in Idaho (+7.6 permil to 10.0 permil). Therefore, the oxygen isotope signature of epidote-bearing calc-alkalic plutons within the CSF is perhaps a unique characteristic and this once again reflects source isotope characteristics.

c. Sulfur isotopes: These isotopes potentially represent an important tool in granitoid petrogenesis. Magnetite-series granitoids in Japan have positive $\delta^{34} \mathrm{~S}$ values (from +1 permil to +9 permil) while ilmenite-series granitoids exhibit negative values $(-11$ permil to +1 permil) as observed by Sasaki \& Ishihara (1979). Similar behaviour was recently observed in magnetite- and ilmenite-series granitoids of the Sierra Nevada batholith, North America (Ishihara \& Sasaki 1989).

Two representative samples from the CSF epidote-bearing granitoids (Santo Antônio and Emas batholiths), have been analysed at Tsukuba, Japan. Although they have similarly hjgh $\delta^{18} \mathrm{O}$ values, they yielded positive, but discrepant $\delta^{34} \mathrm{~S}(\mathrm{CDT})$ values. The Emas batholith displayed a value of +1 permu typical for mantle rocks, while the Santo Antônio stock showed a value of +9.3 permil, much heavier than expected for magmas derived from crustal or normal mantle sources.

DEPTH OF EMPLACEMENT Hammarstrom \& Zen $(1983,1985,1986)$ proposed that differences in the $\mathrm{Al}$ content of calcic amphiboles are directly related to the depth of emplacement of their host plutons. Following this assumption, an empirical geobarometer to estimate pressure with an error of $\pm 3 \mathrm{kbar}$ was then proposed. Hollister et al. (1987) refined this geobarometer and reduced this error to \pm 1 kbar. In both cases, the empirical geobarometer, proposed for synmetamorphic, metaluminous, calc-alkalic plutonic complexes of tonalite and granodiorite compositions, was based on total $\mathrm{Al}$ content of honblende and pressure of crystallization was independently estimate from metamorphic assemblages in the country rock (in the range $<1$ kbar to 8 kbar).

The composition of amphiboles in igneous rocks varies with bulk composition, pressure, temperature, and oxygen fugacity and there are usually too many degrees of freedom for a single compositional parameter to define pressure or temperature (Rutter et al. 1989). Hollister et al. (1987), however, have shown theoretically and empirically that in some near-solidus calc-alkalic plutons, the aluminum content of amphibole is controlled solely by total pressure. This geobarometer is therefore restricted to rocks in the stages of final consolidation, i.e., near-solidus, which should have the magmatic assemblage: quartz, plagioclase, orthoclase, biotite, amphibole, magnetite, titanite, with or without epidote. This phase assemblage, melt and fluid buffer the Al content of coexisting hornblendes.

Recently, Johnson \& Rutherford (1989) and Ruther et al (1989) added experimental calibration for the Al-in-hornblende geobarometer. The former showed that experimental calibration differs from the empirical ones, especially above $5 \mathrm{kbar}$, and that the $\mathrm{Al}$ content of hornblende in equilibrium with the required phase assemblage is greater for a given total pressure than previously thought. With the new equation proposed $\left(\mathrm{P}=-3.46+4.23(\mathrm{Al})^{\mathrm{t}}\right)$, the geobarometer's uncertainty was reduced to $\pm 0.5 \mathrm{kbar}$.

Analyses of hornblendes from five representative calc-alkalic, epidote-bearing granitoids of the Conceição-type are found in table 3. Analyses of hornblendes from the epidote-bearing facies of the Brejinho batholith which intruded rocks of the basement of the CSF are also included. In all cases, hornblendes were analysed next to their margins for $\mathrm{Si}, \mathrm{Al}, \mathrm{Fe}$ (total), $\mathrm{Mg}, \mathrm{Mn}, \mathrm{Ti}, \mathrm{Na}, \mathrm{K}$ and $\mathrm{Ca}$ using a wavelength dispersive system (WDS). Analyses are reported in major oxides, cation proportions, along cation sums and pressure estimates using the equation by Johnson \& Rutherford (1989). Results shown represent averages of 5 to 10 complete analyses per representative sample (each analysis represents an average of 5 points with 10 peak readings at 10 seconds each). Chlorine and fluorine are present in trivial amounts (around $0.01 \%$ ) in all cases.

The epidote-bearing, calc-alkalic peraluminous plutons have the appropriate assemblage to buffer the $\mathrm{Al}$ content of the coexisting amphibole. Hornblende from these plutons (Penaforte, Ipueiras, Conceição and Santo Antônio stocks) yielded values varying from $5.8 \mathrm{kbar}$ (Ipueiras stock) to 7.0 kbar (Penaforte stock), a pressure range expected for rocks of this kind. However, hornblendes from the Emas granodiorite batholith (Goist 1989) yielded pressure of solidification around 5 kbar, when recalculated according to Johnson \& Rutherford's equation. Hornblende from quartz-diorite enclaves at Santo Antônio and Conceição-type locality yielded values of $4.4 \mathrm{kbar}$ and $4.7 \mathrm{kbar}$, probably due to loss of $\mathrm{Al}$ during granular epidote formation along the hornblende boundaries in contact with plagioclase, attested by higher $\mathrm{Al}$ values towards the core of amphiboles. The margins of the 


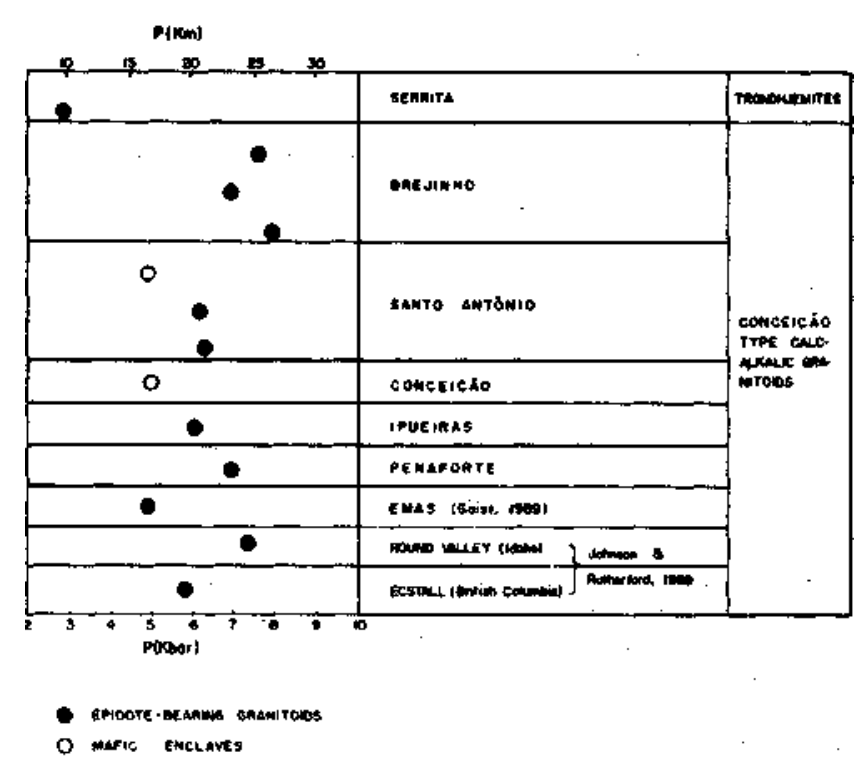

Figure 6 - Al-in-hornblendes pressure estimates (solid circles) for epidote-bearing calc-alkalic granitoids in the CSF. Open circles represent pressure estimates for hornblende in quartz diorite enclaves. Pressure estimates (Johnson \& Rutherford, 1989) for Round Valley (Idaho) and Ecstatt (British Columbia) plutons were added for comparison

Figura 6 - Pressões baseadas nos teores de Al na hornblenda (círculos cheios) para os granitóides cálcio-alcalinos com epfdoto no CSF. Círculos abertos representam pressões estimadas para hornblenda nos encraves quartzo-diorítícos. Pressões (Johnson \& Rutherford, 1989) para os plutões de Round Valley (Idaho) e Ecstall (Columbia Britânica) foram adicionados para comparação hornblende phenocrysts from the biotite monzogranite facies of the Brejinho batholith yielded values between $6.2 \mathrm{kbar}$ and $7.3 \mathrm{kbar}$

Sial \& Ferreira (1990) estimated the pressure of crystallization for hornblendes in the epidote-bearing, trondhjemitic leucotonalite at Serrita as being around 2.9 kbar. However, these rocks contain primary muscovite and therefore its mineral assemblage is not exactly the one for which the geobarometer was calibrated. Besides, epidote coexists with albite implying that one of them generated by a secondary process (albitization?) that eventually could have affected the amphibole composition).

Hornblendes from three epidote-free K-calc-alkalic plutons (Serra da Lagoinha along the northeast boundary of the CSF and Monte das Cameleiras outside the CSD) yielded values between $3.0 \mathrm{kbar}$ and $4.7 \mathrm{kbar}$ (recalculated from Sial etal. 1989, using Johnson \& Rutherford's equation.

In the light of the present data, the epidote-bearing calc-alkalic, peraluminous granitoids in the central portion of the CSF were emplaced at slightly higher pressure $(6 \mathrm{kbar}$ to $7 \mathrm{kbar}$ ) than the epidote-free K-alkalic granitoids (around 4 kbar) by the northern of the CSF.

CONCLUSIONS Epidote-bearing granitoids formed in the Phanerozoic, as well as in the Precambrian times. In only Late Precambrian granitoids of this kind are known. In the CSF they are mostly peraluminous, display very high $\delta^{18} \mathrm{O}$ and intruded phyflites. In contrast, the Serido epidote-bearing granitoids are metaluminous, exhibit lower $\delta^{18} \mathrm{O}$ values and intruded gneisses.

The $\delta^{18} \mathrm{O}$-enriched amphibolite fragments, widespread in the Conceição-type granitoids in the CSF, suggest a basaltic source for the parental magma. The peraluminous nature of most of these generations is explained by the assumption that minimum partial melts of basaltic rocks are indeed

Table 3 - Analyses of hornblende from some epidote-bearing cak-alkalic plutons in the CSF and pressure estimates Tabela 3 - Análises de horblenda de alguns plutons cálcio-alcalinos com epídoto no CSF e estimativas de pressão

\begin{tabular}{|c|c|c|c|c|c|c|c|c|c|c|c|c|c|}
\hline \multicolumn{11}{|c|}{ Plutons intruding Cachoeitinha metaediments } & \multirow{2}{*}{\multicolumn{3}{|c|}{$\frac{\text { Plutons intruding the basement }}{\text { Brejinho }}$}} \\
\hline \multicolumn{4}{|c|}{ Santo Antuito Stock } & \multirow{2}{*}{\begin{tabular}{|l} 
Pentaforte \\
SER-77
\end{tabular}} & \multirow{2}{*}{$\begin{array}{l}\text { Tptent } \\
\text { SER-86 }\end{array}$} & \multicolumn{2}{|c|}{ Conedgio } & \multicolumn{2}{|c|}{ Enmp } & \multirow[b]{2}{*}{$10-18$} & & & \\
\hline$w$ & SER-45 & SER-47 & SER $-47 * *$ & & & $\mathbf{T L} * *$ & $8-14$ & 8-18 & $10-11$ & & ITTM-22 & TTIM-50A & TTIM-50B \\
\hline $\begin{array}{c}\mathrm{SO}_{2} \\
\mathrm{THO}_{2} \\
\mathrm{Al}_{2} \mathrm{O}_{3} \\
\mathrm{FeO} \\
\mathrm{MrO} \\
\mathrm{MgO} \\
\mathrm{CaO} \\
\mathrm{Ne}_{2} \mathrm{O} \\
\mathrm{K}_{2} \mathrm{O} \\
\text { Tot!l }\end{array}$ & $\begin{array}{r}44,00 \\
0,80 \\
12,90 \\
18,60 \\
0,30 \\
9,00 \\
11.40 \\
1.70 \\
1.40 \\
100,17\end{array}$ & $\begin{array}{r}42.00 \\
1,25 \\
12.55 \\
18.20 \\
0.81 \\
8.90 \\
12.74 \\
1.00 \\
1.45 \\
97.99\end{array}$ & $\begin{array}{r}45,50 \\
0,70 \\
10,60 \\
16,30 \\
0.30 \\
10,80 \\
11.40 \\
1.70 \\
1.20 \\
98.19\end{array}$ & $\begin{array}{r}44.80 \\
1.40 \\
14.60 \\
14.60 \\
0.35 \\
10.70 \\
10.60 \\
1.60 \\
0.90 \\
99.22\end{array}$ & $\begin{array}{r}43.50 \\
1.00 \\
12.40 \\
18.70 \\
0.25 \\
8.20 \\
11.20 \\
1.60 \\
1.60 \\
98.21\end{array}$ & $\begin{array}{r}44,80 \\
1.10 \\
11.10 \\
16,60 \\
0.35 \\
10,30 \\
11.40 \\
1.60 \\
1.10 \\
98,01\end{array}$ & $\begin{array}{r}42.26 \\
1.10 \\
11.60 \\
17.97 \\
- \\
9.88 \\
11.86 \\
1.70 \\
1.61 \\
97.98\end{array}$ & $\begin{array}{r}43.02 \\
1.20 \\
11.42 \\
17.93 \\
- \\
10.97 \\
12.35 \\
1.92 \\
1.38 \\
99.59\end{array}$ & $\begin{array}{r}42.22 \\
1.29 \\
11.36 \\
17.94 \\
- \\
10.51 \\
11.64 \\
1.68 \\
1.72 \\
98.75\end{array}$ & $\begin{array}{r}41.71 \\
1.18 \\
11.26 \\
18.36 \\
- \\
10.30 \\
11.79 \\
1.69 \\
1.52 \\
98.24\end{array}$ & $\begin{array}{r}40.30 \\
0.35 \\
13,80 \\
22,70 \\
0,00 \\
6,60 \\
12,70 \\
2,10 \\
1.75 \\
100,30\end{array}$ & $\begin{array}{r}42.30 \\
0,40 \\
12,80 \\
20,00 \\
0,00 \\
8,40 \\
12.90 \\
0,55 \\
1,40 \\
98.77\end{array}$ & $\begin{array}{r}42.50 \\
0.45 \\
13.80 \\
20.30 \\
0.00 \\
7.80 \\
12.35 \\
0.45 \\
1.40 \\
99.04\end{array}$ \\
\hline \multicolumn{14}{|c|}{ Cations chleulated on the busits of 23 oxygens } \\
\hline $\begin{array}{c}\mathrm{Si} \\
\mathrm{Al} \\
\mathrm{Fe} \\
\mathrm{Mg} \\
\mathrm{CA} \\
\mathrm{Ma} \\
\mathrm{K} \\
\mathrm{Ti} \\
\mathrm{Mn}\end{array}$ & $\begin{array}{l}6.51 \\
2.23 \\
2.28 \\
1.96 \\
1.79 \\
0.48 \\
0.26 \\
0.09 \\
0.04\end{array}$ & $\begin{array}{l}6.35 \\
2.24 \\
2.29 \\
2.00 \\
2.06 \\
0.29 \\
0.28 \\
0.14 \\
0.00\end{array}$ & $\begin{array}{l}6.73 \\
1.85 \\
2.01 \\
2.38 \\
1.80 \\
0.48 \\
0.22 \\
0.07 \\
0.03\end{array}$ & $\begin{array}{l}6.46 \\
2.48 \\
1.76 \\
2.29 \\
1.63 \\
0.44 \\
0.17 \\
0.15 \\
0.04\end{array}$ & $\begin{array}{l}6.53 \\
2.19 \\
2.35 \\
1.83 \\
1.80 \\
0.46 \\
0.30 \\
0.11 \\
0.03\end{array}$ & $\begin{array}{l}6.65 \\
1.94 \\
2.06 \\
2.27 \\
1.81 \\
0.46 \\
0.20 \\
0.12 \\
0.04\end{array}$ & $\begin{array}{l}6.35 \\
2.05 \\
2.27 \\
2.21 \\
1.92 \\
0.49 \\
0.31 \\
0.12 \\
0.00\end{array}$ & $\begin{array}{l}6.37 \\
1.99 \\
2.22 \\
2.29 \\
1.97 \\
0.53 \\
0.26 \\
0.13 \\
0.00\end{array}$ & $\begin{array}{l}6.26 \\
1.99 \\
2.29 \\
2.32 \\
1.88 \\
0.48 \\
0.33 \\
0.14 \\
0.05\end{array}$ & $\begin{array}{l}6.23 \\
1.99 \\
2.39 \\
2.29 \\
1.92 \\
0.49 \\
0.29 \\
0.13 \\
0.06\end{array}$ & $\begin{array}{l}6.14 \\
2.54 \\
2.83 \\
1.44 \\
2.01 \\
0.54 \\
0.39 \\
9.07 \\
0.00\end{array}$ & $\begin{array}{l}6.38 \\
2.28 \\
2.52 \\
1.89 \\
2.08 \\
0.15 \\
0.26 \\
0.04 \\
0.00\end{array}$ & $\begin{array}{l}6.37 \\
2.44 \\
2.54 \\
1.74 \\
1.98 \\
0.13 \\
0.26 \\
0.05 \\
0.00\end{array}$ \\
\hline $\begin{array}{l}\text { Cation } \\
\text { Sum }\end{array}$ & 15.65 & 15.67 & 15.62 & $\mathbf{1 5 . 4 5}$ & 15.63 & $\mathbf{1 5 . 5 8}$ & 15.72 & 15.76 & 15.74 & 15.79 & 15.96 & 15.63 & 15.54 \\
\hline $\begin{array}{c}P(+0,5) \\
\text { kbar }\end{array}$ & 6.0 & 6.0 & 4.4 & 7.0 & 5.8 & 4.2 & 52 & 5.0 & 5.0 & 5.0 & 7.3 & 6.2 & 69 \\
\hline
\end{tabular}


peralumimnous (Helz 1976)

Initially, magmatic epidote-bearing plutons were considered to be emplaced only into rocks undergoing metamorphism at high $\mathrm{P}$ and $\mathrm{T}$ and should not be capable of rising large distance before solidifying (Zen \& Hammarstron, 1984). However, it has been observed by Moench (1986), Tufloch (1986) and Saavedra et al. (1987) that plutons of this kind can intrude low-grade metamorphic rocks. The Conceição-type plutons in the CSF constitute another example. The difference here is that pressures of solidification are in the lower range ( 6 kbar - 7 kbar) predicted by Zen \&

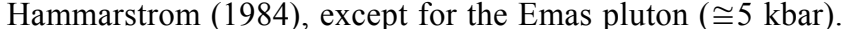
The possibility that the high $\mathrm{P}$, low $\mathrm{T}$ conditions prevailed regionally during the time of emplacement of these plutons does not find immediate support in recent study by Lima (1989) who preliminarly determined $\mathrm{P}$ of $2 \mathrm{kbar}-5 \mathrm{kbar}$ and $\mathrm{T}$ of $400^{\circ} \mathrm{C}-700^{\circ} \mathrm{C}$ for CSF metasediments (it does not rule out, however, the possibility that in the central zone of the belt a higher $\mathrm{P}$ regime was active, since values around $5 \mathrm{kbar}$ were found near this zone). This puzzling situation is perhaps explained by diapiric migration of these plutons to shallow depths in the crust, a hypothesis to be tested through future structural studies.

Currently, it seem that granitoids in the CSF and SFB differ in their origin and/or evolution. Such difference resulted from dissimilarities in the chemical characteristics of the source rock and/or divergent tectonic evolution ot these two belts. The present picture can perhaps be changed when more substantial volume of data becomes available.

The petrographical and geochemical differences among epidote-bearing granitoids in these two belts and North American or Argentinian equivalent plutons indicate that epidote can form in granitic magmas generated from chemically and isotopically dissimilar source rocks. Processes leading to their formation have occurred repeatedly through geological time and these magmas intruded different crustal levels in different types of crust.

Acknowledgements All oxygen isotope analyses were performed at the University of Georgia, USA. I am thankful to Dr. D. B. Wenner for his assistance. Ronald V. Fodor from North Carolina State University did part of the microprobe analyses. Sulfur isotopes were carried out at Tsukuba, Japan, with the assistance of Prof. A. Sasaki. Dr. E-An Zen from the USGS in Reston, Virginia, provided representative samples of typical epidote-bearing granitoids from Idaho for which I am grateful. Discussions with Prof. James A. Whitney from the University of Georgia were very beneficial and contributed to improve the original manuscript. Finally, I want to thank the FTNEP Agency which through the PADCT program partially supported this study.

\section{REFERENCES}

ALMEIDA, F.F.M. de; LEONARDOS, O.H.; VALENCA, J. 1971 Review on Granitic Rocks of Northeast South America. Recife, IUGS/UNESCO. $41 \mathrm{p}$

ANGELIM, L.A.A. 1988. Santa Filomena Folha SC. 24-V-A-1JI, Estados de Pernambuco e Paraíba. Brasília, DNPM, Levantamentos Geológicos Básicos. 166p (Texto explicativo).

BRITO NEVES, B. B. DE 1983. Mapa Geológico do Nordeste Oriental do Brasil, Escala 1/1,000,000. São Paulo. 177p. (Tese Livre-Doc, IG/Universidade de São Paulo).

D AWES, R.L. 1988. Constraints on the petrogenesis of magmatic epidote-bearing dikes, Front Range, Colorado. In: GEOL. SOC AMER. ANNUAL MEET., Denver, Colorado, GSA 1988. Abstracts with Programs, 20: A71-A72.

EVANS, B. W. \& VANCE, J. A. 1987. Epidote phenocrysts in dacitic dikes. Boulder, Colorado. Contr. Min. Petrol., 96:178-185

GOIST, T. O. 1989. Petrology and geochemistry of the Emas Pluton Northeastern Brazil. Athens. 158 p. (Master of Science thesis, University of Georgia).

HAMMARSTROM, J. \& ZEN, E-AN 1983. Possible use of Al content in hornblende as a geobarometer for plutonic rocks. In: GEOL. SOC. AMER. ANNUAL MEET., 1983. Indianopolis, Indiana, GS A, Abstracts with Programs, 15:590.

HAMMARSTROM, J. \& ZEN, E-AN 1985. An empirical equation for igneous calcic amphibole geobarometry. In: GEOL. SOC. AMER. ANNUAL MEET. Orlando, Florida, Abstracts with Programs, GSA 17:602

HAMMARSTROM, J. \& ZEN, E-AN 71986. Aluminum in hornblende: an empirical igneous geobarometer. Am. Miner., 71:1297-1313

HELZ, R.T. 1976. Phase relations of basalts in melting ranges at $\mathrm{PH} 2 \mathrm{O}$ $=5 \mathrm{~kb}$. Part II melt compositions. Jour. Petrol. 17:139-193.

HOLLISTER, L. S.; GRISSOM, G.C.; PETERS, E.K.; STOWELL, H.H.; SISSON. V.B. 1987. Confirmation of the empirical correlation of $\mathrm{Al}$ in hornblende with pressure of solidification. Amer. Miner 72:2231-239.

ISHIHARA, S. \& SASAKI, A. 1989. Sulfur isotopic ratios of the magnetite-series and ilmenite-series granitoids of the Sierra Nevada batholith- a reconnaissance study. Geology, 17:788-791.

JOHNSON, M.C. \& RUTHERFORD, MJ. 1989. Experimental calibration of the aluminum in hornblende geobarometer with application to Long Valley Caldera (California) volcanic rocks. Geology, 17:837-841.

LAMEYRE, J. \& BOWDEN, P. 1982. Plutonic rock types series discrination of various granitoid series and related rocks. Jour. Volcan.Geoth.Res., 14:169-186.

LIMA, E.S. 1989. Evolução tectono-metamórfica durante o Proterozóico do Segmento Mediano do Dom\&úo Estrutural Central, Nordeste do Brasil. Recife. 137p. (Tese Professor-Titular, Universidade Federal de Pernambuco)
LOISELLE, M. C. \& WONES, D. R. 1979. Characteristics and models for the origin of A-type granites. (Unpublished).

MANDUCA C.; SIAL, A.N.; FERREIRA, V.P.; TAYLOR, H.P. 1989. $\delta^{18} \mathrm{O}$ from two contrasting epidote-bearing calc-alkalic intrusive suites: Hazard Creek Complex, Idaho and Conceição-type intrusives, Brazil. In: GEOL, SOC. AMER. ANNUAL MEET., St. Louis, Missouri, 1989. GSA, Abstracts with Programs, 21: A165.

MENOR, E.A. \& SIAL, A.N. 1969. Contribuição à Geologia da Meia Ouadrícula Este de Afogados, PE. Recife, CNPq. 22p. (Rei. Final)

MILLER, C.F.; STODDARD, E.F.; BREDFISH, L.J.; DOLLASE, W.A. 1981. Composition of plutonic muscovite: genetic implications. Can. Journ. of Earth Sci., 19:25-34.

MOENCH, R.H 1986. Comment on "Implications of magmatic epidote-bearing plutons on crustal evolution in the accreted terranes of Northwestern North America" and "Magmatic epidote and its petrologic significance". Geology, 14:187-188.

NANEY, M.T. 1983. Phase equilibrium of rock-forming ferromagnesian silicates in granitic systems, Am. Jour. Sci., 283:993-1033.

RUTTER, MJ.; LAAN, S.R. VAN DER; WYLLIE, P.J. 1989. Experimental data for a proposed empirical igneous geobarometer: Aluminum in hornblende at 10 kbar pressure. Geology, 17:897-900.

SAAVEDRA, J ; TOSELLI, AJ ; TOSELLI, J N.R. de; RAPELA, C.W. 1987. Role of tectonism and fractional crystallization in the origin of Lower Paleozoic epidote-bearing granitoids, Northwestern Argentina. Geology, 15:709-713.

SASAKI, A. \& ISHIHARA, S. 1979. Sulfur isotopic composition of the magnetite-series and ilmenite-series granitoids in Japan. Contr, Min. Petrol., 68:107-115.

SIAL, A.N. 1984. Padrão regional de isotopes de oxigênio em granitóides do espaço Cachoeirinha, Nordeste do Brasil. In: CONGR. BRAS. GEÓL 33, Rio de Janeiro, 1984. Anais.. Rio de Janeiro, SBG. p.2170-2722.

SIAL, A.N. 1986. Granite types in Northeast Brazil: current knowledge. Rev. Bras. Geoc. 16(1):54-72.

SIAL, A.N. 1987. Granitic rocks of Northeast Brazil. In: INTERN. SYMP. GRANITES AND ASSOCIATED MINERALIZATIONS, Salvador, 1987. Extended Abstracts. Salvador, Sup. Geol. Rec. Min., p.61-69.

SIAL, A.N. \& MENOR, E.A. 1969. Geologia da Meia Quadrícula Sul de Taquaritinga do Norte. Recife, UFPE, Estudos e Pesquisas, 1(1): 49 p. (Série B).

SIAL, A.N. \& FERREIRA, V.P. 1989. Granitóides cálcio-alcalinps com epidoto no Domínio Estrutural Central, Nordeste do Brasil. In: SIMP. GEOL. NORDESTE, 13, Fortaleza, 1989. Atas.. Fortaleza, SBG. p.1 16-118. 
SIAL, A.N. \& FERREIRA, V.P. 1990. Granitoids in Northeast Brazil: oxygen and sulfur isotope compositions and depths of emplacement. Jour, of South Amer. Earth Sci., 3(2): (in press)

SIAL, A.N.; MARIANO, G.; FERREIRA, V.P. 1989. Isotope geochemistry of Brasil age, coarsely porphyritic, K-calc-alkalic granitoids and associated K-diorites, Northeast Brazil. In: CONGR. BRAS. GEOQUIM., 2, Rio de Janeiro, 1980. Anais... Rio de Janeiro, SBG. p.229-240.

SIAL, A.N.; LIMA, E.S.; PESSOA, D.A.; CASTRO, C.; VILLARROEL, H.S.; RODRIGUES DA SILVA, M.R.; BORBA, G.S.; LIMA, G.R. 1981. Geoquímica de dois stocks granodiorfticos de Serrita (PE): elementos maiores. Estudos e Pesquisas, 4:27-52

SILVA, H.F. 1989. Alguns aspectos petrográficos do batólito de Quixadá(CE).Rev.Bras. Geoc., 19(1):101-107.

SOUZA, K. Petrologia e geoquímica do batólito Brasiliano cálcio-alcalino com epidoto magmático de São Rafael, RN (Nordeste do Brasil). Recife. (Dissertação de Mestrado, Universidade Federal de Pernambuco), (em preparação).

SOUZA, K. \& SIAL, A.N. 1989. Petrologia do batólito granftico de São Rafael, Rio Grande do Norte, Brasil, e a importância da presença de epidoto magmático. In: SIMP. GEOL. NORDESTE, 13, Fortaleza, 1989. Atas... Fortaleza, SBG. p. 137-138.
STRECKEISEN, A. 1973. Plutonic rocks. Classification and nomenclature recommended by the IUGS Subcommission of the systematics of igneous rocks. Geotimes, 188(10):26-30

TOSELLI, AJ.; TOSELLI, J.N.R.; SAAVEDRA, J. 1987. Petrological and geochemical considerations about the Lower Paleozoic granitoids of the Pampean Ranges, Argentina. Rev. Bras.Geoc., 17(4):619-622.

TULLOCH, AJ. 1986. Comment on "Implications of magmatic epidote-bearing plutons on crustal evoluton in the accreted terranes of Northwestern North America" and "Magmatic epidote and its petrologic significance". Geology, 14:186-187.

ZEN, E-AN 1985. Implications of magmatic epidote-bearing plutons on crustal evolution in accreted terranes of Northwestern North America. Geology, 13:266-269.

ZEN, E-AN \& HAMMARSTROM, J. 1984. Magmatic epidote and its petrologic significance. Geology, 12:515-518.

MANUSCRITO A661 Recebido em 24 de maio de 1990 Revisão do autor em 27 de julho de 1990 Revisão aceita em 31 de julho de 1990 